Karadeniz Uluslararası Bilimsel Dergi

Volume: 48, Winter-2020, p. (327-353)

ISSN: 1308-6200 DOI Number: https://doi.org/10.17498/kdeniz.833275

Research Article

Received: November 1, 2020 | Accepted: December 8, 2020

This article was checked by ithenticate.

\title{
TYANA ROMA HAMAMI KAZILARINDA ORTAYA ÇIKAN SÜTUN BAŞLIK PARÇALARI
}

\section{COLUMN HEADPIECES FROM THE EXCAVATIONS OF TYANA ROMAN BATH}

\section{КАПИТЕЛИ КОЛОНН, НАЙДЕННЫЕ ПРИ РАСКОПКАХ РИМСКОЙ БАНИ В ТИАНЕ}

\author{
Tahir GÜRKAN* \\ Osman DOĞANAY**
}

\section{ÖZET}

Kapadokya, antik dönemde kuzeyinde Pontos, batısında Lykaonia ve Galatia, güneyinde Kilikia ve doğusunda Armenia Minor bölgeleri ile sınırlı olan alandır. Bölge, Mezopotamya ile Anadolu bağlantısının sağlandığı Kilikya Kapılarının bulunmasından dolayı önemli bir yere sahiptir. Bölgede önemli bir kent olan Tyana ise farklı zamanlarda iki kere başkent olmuştur. Kent zaman içinde farklı medeniyetler tarafindan farklı isimlerle anılmıştır. Yapılan araştırmalarda kentin adı Hitit Çağında Tuwanuwa, Geç Hitit döneminde Tuwana, Pers ve Hellenler Dana, Roma döneminde Tyana, Osmanlı döneminde Kilisehisar ve Cumhuriyet döneminde ise Kemerhisar olarak bilinmektedir. Kent açısından önemli olan diğer bir konu ise ünlü filozof Apollonius'un doğduğu yer olmasıdır. Romanın Anadolu'da hâkimiyetinin artmasının ardından Severuslar döneminde kente verilen önem artmıştır. Bu önemin artmasının en önemli nedeni Julia Domna ve Septimius Severus'un Tyanalı Apollonius'a olan hayranlığıydı. Dolayısıyla oğlu Caracalla da Apollonius'a ilgi duymuştur. Özellikle Severuslar zamanında kentte çeşitli imar faaliyetleri yürütüldüğü düşünülmektedir. Su kemerleri, Roma Havuzu ve Roma Hamamı başta olmak üzere çeşitli fonksiyonlarda yapılar inşa edilmiştir. Roma Hamamı ise antik kentin güneyinde bulunmaktadır. Hamamın suyu ise kentin kuzeydoğusunda Köşkhöyük olarak bilinen yerden ve yanında bulunan Roma Havuzunda biriktirilen sularla kente doğru inşa edilen su kemerleri vasıtasıyla kente getirilmekteydi. Dolayısıyla hamamın mimari parçaları ise Severuslar dönemine yani MS 3. yüzyıla tarihlenmektedir.

Anahtar Kelimeler: Kapadokya, Tyana, Hamam, Caracalla, Tyanalı Apollonius

\footnotetext{
*ORCID: 0000-0003-1290-6638. Selçuk Üniversitesi, Edebiyat Fakültesi, Arkeoloji Bölümü, tahir_gurkan1994@hotmail.com

${ }^{* *}$ ORCID: 0000-0002-7095-9466. Doç. Dr. Aksaray Üniversitesi, Fen-Edebiyat Fakültesi, Arkeoloji Bölümü, osmandoganay@ hotmail.com
} 


\title{
Tyana Roma Hamamı Kazılarında Ortaya Çıkan Sütun Başıı Parçaları
}

\begin{abstract}
Cappadocia; Pontos in the north, Lycaonia and Galatia in the west, Cilicia in the south and Armenia Minor in the east. The region has an important place due to the presence of the Cilician Gates where Mesopotamia and Anatolia are connected. Tyana is an important city in the region due to its location. The city has been called by different names by different civilizations over time. The name of the city is known as Tuwanuwa in the Hittite Age, Tuwana in the Late Hittite Period, Dana the Persians and Hellenes, Tyana in the Roman period, Kilisehisar in the Ottoman period and Kemerhisar in the Republic period. Another important issue for the city is that it is the place where the famous philosopher Apollonius was born. The importance given to the city increased during the Severus Dynasty in the Roman Imperial Age. The most important reason for this increase was the admiration of Iulia Domna and Septimius Severus to Apollonius of Tyana. Consequently, his son Caracalla was also interested in Apollonius. Especially during the reign of Emperor Caracalla carried out various reconstruction activities in the city. Aqueducts, Roman Pool and Roman Baths were built in various functions. The Roman Bath is located to the south of the ancient city. The water of the bath was collected in the Roman Pool near the mound known as Köşkhöyük in the northeast of the city and was brought to the city through aqueducts built towards the city and provided through the trunks. Therefore, the architectural fragments of the at hare dated to the Severus period, that is to the 3rd century $\mathrm{AD}$.
\end{abstract}

Keywords: Cappadocia, Tyana, Bath, Caracalla, Apollonius of Tyana

\section{АННОТАЦИЯ}

Каппадокия - это область, ограниченная Понтосом на севере, Ликаонией и Галатией на западе, Киликией на юге и Малой Арменией на востоке. Область занимает важное место благодаря наличию Киликийских ворот, через которые соединяются Месопотамия и Анатолия. Тяна, важный город региона, был столицей дважды в разное время. После того, как римское господство в Анатолии усилилось, значение, придаваемое городу, возросло в период Севера. С течением времени разные цивилизации называли город разными именами. Название города известно как Туванува в хеттский период, Тувана в поздний хеттский период, Дана у персов и эллинов, Тиана в римский период, Килисехисар в период Османской империи и Кемерхисар в период республики. Еще один важный момент для города - это место, где родился знаменитый философ Аполлоний. Важнейшей причиной этого роста было восхищение Юлией Домной и Септимием Севером Аполлонием Тяньанским. Поэтому его сын Каракалла заинтересовался и Аполлонием. Считается, что в городе проводились различные мероприятия по зонированию, особенно во времена Северуса. Были построены сооружения с различными функциями, особенно акведуки, римский бассейн и римская баня. Римская баня расположена на юге древнего города. Вода в баню поступала в город из места, известного как Köşkhöyük на северо-востоке города и через водопроводы, построенные по направлению к городу с водой, собранной в расположенном рядом с ним римском бассейне. Поэтому архитектурные части бани датируются северанским периодом, то есть 3-м веком нашей эры.

Ключевые слова: Каппадокия, Тяна, Баня, Каракалла, Аполлоний из Тяни 


\section{1- Giriş}

Günümüzde Niğde İlinin $23 \mathrm{~km}$ güneybatısında, Bor İlçesinin $5 \mathrm{~km}$ güneydoğusunda bulunan Kemerhisar Beldesi'nde (Resim 1), kuzeyden Melendiz Dağları, güneyden Toros silsilesinin uzantıları olan Bolkar Dağları arasında bulunan Tyana Kenti, antik dönemde Kapadokya Bölgesi'nin güneyinde Kilikya'yı Kapadokya'ya bağlayan tarihi yollardan biri üzerinde bulunmaktadır. Sözü edilen bu tarihi yol, Toros geçitlerinden biri olan Gülek Boğazı geçidinden ayrılan yollardan biri olup, Tyana'dan geçerek Kayseri'ye (Mazaka- Kaesareia) uzanmaktayd. Yani Kent, Anadolu'yu Suriye ile birlikte Filistin'e ve Mezopotamya'ya bağlayan yollar üstünde bulunuyordu (Hild, 1977, s.41-59; Berges ve Nolle, 2000, s.449-457). Kentin böyle bir yol üzerinde bulunmasından dolayı birçok defa farklı uygarlık tarafindan ele geçirilmiştir.

Tyana'nın önemli bir kent olmasının başlıca nedenleri bölgeden geçen önemli yollar üzerinde bulunmasından dolayıdır. İlk önemli yollardan birisi İstanbul (Byzantion) ve Ankara (Ankyra) üzerinden gelerek Kızılırmak (Halys) kavisi yoluyla Tuz Gölü'nün (Tatta Limne) doğu tarafından Garsauratis (Colonia Arkhelais-Aksaray) ile Tyana'ya (Kemerhisar) ve Kilikia Kapıları'na giden yoldur (Lloyd, 1998, s.238). Bu yol sonradan, Hıristiyanlık döneminde Küdüs'e giden hacılar tarafından yoğun olarak kullanıldığı için Hacı Yolu (French, 1981, s.16) olarak adlandırılmıştır (Sevin, 1998, s.50)(Resim 2).

Antik dönem coğrafyacılarından Strabon ve Plinius Tyana kenti hakkında bilgi veren önemli yazarlardandır. Strabon ve Plinius, kenti Roma egemenliğine girmeden önce ziyaret etmişlerdir. Strabon, Tyana'nın Kilikia Bölgesi'ne geçit veren elverişli konumundan, topraklarının düz ve bereketli olduğundan ve ayrıca güçlü sur duvarlarına sahip bir yerleşme olduğundan bahsetmektedir.

Strabon'a göre kent Kaisareia'dan (Mazaka/Kayseri) ayırt etmek için Tauros yakınlarındaki Eusebeia olarak adlandırılır (Strabon, 12.2.7.) Bu isim V. Ariarathes dönemindeki Yunan kültürünün etkinliğinden ve kral V. Ariarathes'in Eusebes (dindar) (Tekin, 2016, s.159) (MÖ 163-130) unvanına ithafen verildiği düşünülmektedir(Sevin, 1998, s.56). Sadece Tynana kenti değil aynı zamanda Kaisareia (Mazaka/Kayseri) kentinin de Eusebeia (Argaios yanındaki Eusebeia) olarak adlandırılması Kapadokya Bölgesi'nin bu iki önemli kentinin, V. Ariarathes Eusebes Philopator tarafindan, bölgenin Seleukos hâkimiyetinden kurtarılmasından sonra yeniden kurulmuş ve kurucusuna ithafen verilmiş olduğu düşünülmektedir (Ruge, 1948, s.1637-1638; Magie, 1950, s.493; Berges, 2002, s.182-183). Ayrica bu ismin kutsal gölün ve Asbama kaynağının yakınındaki Asbamaios tapınağında Zeus onuruna düzenlenen ayinlerle bağlantılı olabileceği de ifade edilmektedir (Cramer 1832, s.129; Texier 2002, s.572).

Kapadokya eyalet oluncaya kadar Eusebeia ismi kullanmaya devam etmiştir. Ancak eyalet olduktan sonra MS I. yüzyıl başlarında kent için bu adının kullanımı sona ermiştir (Robert, 1946, s.83). Ayrıca Strabon kentin kuruluş mitosu ile ilgili de önemli bilgiler vermektedir. Strabon'a göre Tyana'nın, Asur kraliçesinin adının verildiği Semiramis tepelerinde kurulduğunu anlatmıştır 


\section{Tyana Roma Hamamı Kazılarında Ortaya Çıkan Sütun Başıı Parçaları}

(Strabon, 12.2.7.). Plinius'ta kentin Semiramis tarafindan kurulduğuna katk1 yapmaktadır (Plinius, 6.3.8.).

Strabon, Kapadokya'nın gerek kral I. Arkhelaos (MÖ 36 - MS 17) gerekse ondan önceki krallar döneminde valiliklere ayrıldığından söz etmektedir (Strabon, 12.1.4.). Bu bölünmeye göre adını Tyana'dan alan Tyanitis Valiliği şehir ile birlikte onu çevreleyen ovalık bölgeyi de kapsamıştır. Bu bölge, Torosların dar geçitleri ile sınırlandırılmıştır ve Kilikia'ya doğru uzanan önemli bir geçiş güzergâhıdır (Burton, 2005, s.259). Kentin bulunduğu bölge başlangıçta Kataonia Valiliği'ne bağlı bir yer iken sonradan Kapadokya'nın valiliklere ayrılmasıyla birlikte Tyanitis adı altında ayrı bir idari saha olarak düzenlenmiştir (Texier, 2002, s.568). Tyana, diğer Roma şehirleri ile kıyaslandığında onlar kadar büyük bir kent görünümünde olmasa da sahip olduğu anıtsal yapıların da gösterdiği üzere kuşkusuz kentsel bir görünüm sergilemiştir (Rosada ve Lachin, 2010, s.642).

MS II. yüzyılda Roma imparatorluğun önce Parth daha sonra ise Sasani tehdidi ile karşı karşıya kalmasıyla birlikte kentin önemi giderek artmıştır (Börker ve Berges 1996, s.18). Böylece bu bölge, imparatorluğun doğu sinırlarının güvenliğinin sağlanmasında Roma askeri yönetimi açısından staratejik bir yer haline gelmiştir. MS III. yüzyılda yapılan Sasani seferlerinde Tyana, Roma ordularının Kilikia geçitlerini aşıp Suriye ve daha doğuya ilerlemesinde kullandığ önemli ikmal noktalarından biri haline gelmiştir (Ruge, 1948, s.1639; Magie, 1950, s.717). Kentin askeri açıdan önemli bir saha olması, özellikle MS II-III. yüzyıl dolaylarında buranın ekonomik refah seviyesinin yükselmesini sağlamış ve böylece şehirde geniş ölçekli bir iyileşme meydana gelmiştir (Börker ve Berges, 1996, s.18).

Tyana'nın öneminin artmasını kentte darp edilen sikke basımlarında da görmekteyiz. Kentte, İmparator Nero Dönemi'nde (MS 54-68) sikke basılmıştır. Kentte sikke basma yetkisi bu dönemde gerçekleşen bir doğu seferi dolayısıyla Kapadokya ile Galatia bölgeleri tek bir eyalet olarak düzenlenmiş ve dolayısıyla Tyana kentine sikke basım hakkı verilmiş olmalıdır (Berges ve Nolle 2000, s.488495).

İmparator Nero'dan sonra kentin sikke basımları kesintiye uğramıştır. Bu duruma belki de İmparator Vespasianus'un (MS 69-79) MS 76 yılında, Kapadokya, Galatia ve Pontus bölgelerini tek bir eyalet altında birleştirmesi neden olabilir. Sikke basımları İmparator Trajan Dönemi'nde (MS 98-117) tekrar başlar ve Caracalla Dönemi'ne (MS 211-217) kadar kesintisiz bir şekilde devam eder. Tyana, İmparator Hadrian'ın (MS 117-138) MS 117 yılında, Suriye'den Roma'ya dönüş yolunda uğradığı kentlerden birisidir (Berges ve Nolle 2000, s.361; Birley, 2000, s.134). İmparator Hadrianus'un kente uğradığına en güçlü kanıt Philostaratus'un anlatımlarında ortaya çıkmaktadır. Philostratus, İmparator Hadrian'ın Tyanalı Apollonios'a çok ilgi duyduğunu ve ona ait çok sayıda mektubu Antium'daki villasında sakladığını bildirmektedir (Philostratus, 8.20.). Özellikle imparator Hadrianus (Ruge, 1948, s.1638; Berges ve Nolle 2000, s.368369) ve Caracalla dönemlerinde kent çok sayıda sikke darp etmiştir. Kentte özellikle imparator Caracalla Dönemi'nde sikke basımları en yüksek seviyeye 
çıkmıştır. Tam, yarım ve çeyrek değerde bronz sikkeler darp edilmiştir (Şener, 2019, s.141). Marcus Aurelius (MS 161-180) Döneminde ise Ti. Claudius Gordianus şehirden senatör seçilmiştir (Eck, 2000, s.219).

Roma İmparatorluk Döneminde Hadrianus'tan başlayarak Severuslar dönemine kadar kente verilen önem artmıştır. Bu önemin artmasının en önemli nedenlerinden biri Septimius Severus'un Tyanalı Apollonius'a olan hayranlığıydı. Dolayısıyla oğlu Caracalla da Apollonius'a ilgi duymuştur. Özellikle Severuslar zamanında kentte çeşitli imar faaliyetleri yürütülmüştür. Su kemerleri (Resim 3), Roma Havuzu (Resim 4), Heroon, Zeus Asbamaios'a adanan bir tapınak ve Roma Hamamı başta olmak üzere çeşitli fonksiyonlarda yapılar inşa edildiği düşünülmektedir.

Tyana, Caracalla'nın (MS 211-217) imparatorluğu sırasında oldukça önemli bir yere sahipti. Kent, Caracalla tarafindan MS 213 y1lında Colonia (Berges ve Nolle, 2000, s.341-363; Berges, 2002, s.18; Rosada ve Lachin, 2010, s.196) olarak belirlenmiş ve Antoniana Colonia Tyana olarak adlandırılmışıtır (Berges ve Nolle, 2000, s.341; Berges, 2002, s.17). Tyana'nın Colonia olarak belirlenmesi, Caracalla'nın doğuya düzenleyeceği seferlerde Tyana'nın bulunduğu coğrafi konumdan faydalanma isteğinin bir sonucu olmalıdır. Dolayısıyla Tyana, Suriye'ye uzanan ana yol üzerinde bulunmaktaydı ve stratejik bir konuma sahipti. Şehir aynı zamanda Roma imparatorlarının Suriye'ye yaptıkları gezilerde çoğu kez ziyaret edilmiştir (Berges, 2002, s.183-185).

Tyana'da Severuslar dönemine ait çok sayıda ve büyük kamu yapıları bulunmaktadır (Börker ve Berges, 1996, s.21). İmparator Caracalla ve annesi Julia Domna'nın Tyana'ya büyük katkıları ve yatırımları olmuş, şehirde çok önemli imar faaliyetleri gerçekleştirilmiştir (Rosada ve Lachin, 2008, s.1). İmparator Caracalla Döneminde yapıldığı düşünülen (Rosada ve Lachin, 2011, s.642) kemerler ise kentin güneyine doğru uzanan ve Toros silsilesinin bölgedeki son yamaçları olan tepelerden su getirmek amaciyla inşa edilmiştir. Söz konusu kemerler şehirdeki tüm konutların faydalanabilmesi için önemli ve karmaşık bir hidrolik sistemi ile yapılmıştır. Bu kemerlerin su deposunun şehrin birkaç km kuzeydoğusunda bulunan Köşkhöyük yakınlarındaki $60 \times 20$ m boyutlara sahip olan Roma Havuzu olabileceği düşünülmektedir (Rosada ve Lachin, 2010, s.197).

\section{2- Tyana Roma Hamamı}

Tyana Roma Hamamı antik kentin güneyinde ve 40x42 m boyutlarındadır. Hamam kompleksi modern binaların inşası ile tahribata uğramıştır. Yapının güneyinde, hemen bitişiğinde Sümer İlkokulu ve kuzeyinde ise bir sağlık ocağı bulunmaktadır. Hamamda araştırmalar 1995 yılında kentte yüzey araştırması yapmaya başlayan C. Börker ve D. Berges başkanlığındaki Alman araştırmacılar tarafından yapılmıştır. 2001 yılında İtalyan ekip kentte araştırma yapmaya başlamış ve 2014 yılında sonlandırılmıştır. Daha sonra 2016 yılında Niğde Müzesi başkanlığında Türk araştırma ekibi kente çalışma faaliyetlerine başlamış ve halen devam etmektedir. 


\section{Tyana Roma Hamamı Kazılarında Ortaya Çıkan Sütun Başıı Parçaları}

Konumu itibarıyla hamamın hidroteknik bakımdan şehrin güneyine doğru yapılması Vitruvius'un da bahsettiği gibi hem daha çok güneş alması hem de bölgede çevreye göre alçakta olmasıyla ilgilidir (Vitrivius, 5. 116-117). Bu nedenle, hamam kompleksi şehirdeki yerleşim höyügünün kuzeydoğu ucunda bulunur ve su kemeri ile su kaynağına bağlanır. Su kemerinin su drenaj yüksekliği yaklaşık 111,5 m yüksekliktedir ve bu noktada antik yerleşim höyügünün en üst seviyesinde bulunur.

Buna karşılık, hamamın yapıldığı alan yüksekliği, yaklaşık 1103,3 m ile yerleşim alanının en alçak kısımlarına aittir (Berges ve Nolle, 2000, s.65). Hamamın suyu ise kentin kuzeydoğusunda Köşkpınar olarak bilinen höyügün yanında bulunan Roma Havuzunda biriktirilen sular ile kente doğru inşa edilen su kemerleri vasıtasıyla kente getiriliyor ve künkler ile su dağıtılıyordu (Elalmış, 2007, s.3). Dolayısıyla su kemerlerinin inşasının ilk nedenlerinden biri hamamın suyunun karşılanmasıdır. Hamamın konumunun diğer avantajları ise kirli su atığının kolay ve ısıtma malzemesi temininin kolay sağlanmasıdır.

Roma İmparatorluk Çağında, Severuslar döneminde kente verilen önemin artmasıyla birlikte İmparator Septimius Severus ve oğlu Caracalla zamanlarında kentte çeşitli imar faaliyetleri yürütülmüştür. İşte Roma Hamamı böyle bir dönemde inşa edilmiştir. Dolayısıyla hamamın mimari parçaları MS en erken II. yüzyıl ve daha geç dönemlerere tarihlenmektedir.

Önceki kazı ekibinin raporlarına göre Roma Hamam yapısı 40x42 m boyutlarında kare planlı bir yapıdır (Rosada ve Lachin, 2010, s.204). Olasilıkla Berges ve Nolle'nin önerisine göre daha sonra semerdam çatılı üç tabernae (dükkân) eklenmiştir (Berges ve Nolle, 2000, s.68). Bu yapılar beş geniş odaya sahiptir. Bunlardan apodyterium ve bazilika hamamı (basilica thermarum) uzun duvarları doğu-batı doğrultusunda ve banyo odaları sayılan diğerleri kuzey-güney doğrultusunda yer almışlardır. Söz konusu banyo odalarından frigidarium (soğukluk) ve tepidarium (111klık) doğrudan bazilika hamamı ile bağlantılıydılar ve calidariuma (sıcaklık) geçiş tepidarium içinden sağlanmıştır. Isıtma, kuzey tarafta bulunan ve calidarium ile bazilika hamamı (basilica thermarum) arasında yer alan praefurnium (külhan) ile gerçekleşmiştir (Resim 5).

\section{a-İon Sütun Başılı Parçaları}

1 numaralı volüt parçasında (Katalog No. 1, Resim 6) volüt kıvrımları ve polster (yastık) kısmında ki bitkisel yaprak bezemesi görünmektedir. Yaprak 1.7 $\mathrm{cm}$ kabartma yüksekliğine sahiptir. Öncelikle yaprak işlenişindeki sadelik göze çarpar. Yapraklar muhtemelen balteustan çıkıp volütlere doğru gelmiştir. Ayrıca yaprak damarı tek çizgi halinde ve yaprağın ucuna doğru gelmektedir. Mızrak ucu şeklindeki bu yapraklarda herhangi bir detay işlenmesine gidilmemiştir.

Anadolu genelinde Severuslar dönemine tarihlenen sütun başliklarının birçoğunda olduğu gibi, söz konusu eserde süslemelerdeki biçimsel bozulmalara paralel olarak polsterde yüzeysel olarak işlenmiş daha basit süsleme kompozisyonu yer alır. Kemerhisar' da Etiler okulunda yeni kazı ekibi tarafindan tespit edilen B-İ6 numaralı başlık parçasının ( Resim 7) incelenen eserle benzer yaprak özeliklerine 
sahip olduğu görülmüştür. Başlığın yan yüzündeki yastık şeklindeki polster kısmında kökünden birbirine birleşen yatay yapraklarla bezenmiştir. Mızrak ucu şeklindeki bu yapraklarda herhangi bir detay işlemesine gidilmemiştir. Yan yüzünün orta elemanı olan balteus tek bir hacimli ve yuvarlak formlu bantla oluşturulmuştur. $\mathrm{Bu}$ şeklideki tek yuvarlak bantlı balteus şekillendirmesinin de Attika kökenli olduğu ileri sürülmektedir (Mert, 2002, s.253). B-İ-6 kazı envanter numaralı İon başlık parçası incelendiğinde İ.H. Mert tarafindan Konya Arkeoloji Müzesi'nde tespit edilen Kat.5/Res.15-16 numaralı İon başlı̆g 1 ile olan benzerliği dikkat çeker (Mert, 2002, Kat. 5, Res.15-16). Kentte bulunmuş söz konusu İon başlığının polster kısmından yola çıkarak incelediğimiz İon başlık parçasına ait olabilecek parçanın polster kısmındaki yaprak formları, sadeliği ve volütlerdeki kıvrım benzerlikleri bize tarihleme konusunda yardımcı olmaktadır. Ayrıca tarihleme kriteri olarak çevre bölge, kentlerde bulunan (Çelik, 2019, s.76.; Beykan, 2004, s.106, Kat. 27e.: Kat. 55c; Herrmann, 1988, Pl. CXIV-Fig. 260.; Bingöl, 1980, Lev. 38, Kat. 293) ve Berges ve Nolle'nin Tyana I-II adlı eserlerinde incelendikleri İon başlık parçalarından yola çıkılarak kolayca tarihleme yapılabilmektedir (Berges ve Nolle, 2000, Taf. 88-Kat.127; Taf. 89-Kat.131).

2 numaralı volüt parçası (Katalog No. 2, Resim 8), Kompozit ya da İon sütun başlığına ait olabilecek volüt parçasıdır. Chitham'ın Antik Mimarlıkta Düzenleri ele aldığı kitabında İonik Başlık I olarak tanımladığı başlıktan yola çıkarak İonik bir sütun başlığına ait olabileceği kanısına varabiliriz (Chitham, 2005, s.77). Ayrıca kompozit sütun başlıklarında gördügümüz akanthus ve İon volütünün bir arada kullanımından yola çıkarak eserde iki taraflı bir volüt sarmalının olduğu da söylenebiliriz (Chitham, 2005, s.99) (Resim 9). MS I. yüzyıldan sonra şekillenmeye başlayan kompozit sütun başlıkları MS II. yüzyılın ortalarından itibaren yoğun olarak kullanılmıştır (Başaran, 1999, s.45).

3 numaralı İon başlık parçası (Katalog No. 3, Resim 10) aşrı derecede tahribata uğramıştır. Eser 2003 yılı kazı sezonunda ve hamamın Legnaia (Odunluk) bölümünde bulunmuş bir parçadır. Eserde, volüt ve polster kısmı görülmektedir. Öncelikle yaprak işlenişindeki sadelik göze çarpar. Polster kısmındaki yapraklar muhtemelen balteustan çıkıp volütlere doğru gelmiştir. Mızrak ucu şeklindeki bu yapraklarda herhangi bir detay işlenmesine gidilmemiştir. Anadolu genelinde Severuslar dönemine tarihlenen sütun başlıklarının birçoğunda olduğu gibi söz konusu eserde süslemelerdeki biçimsel bozulmalara paralel olarak polsterde yüzeysel olarak işlenmiş daha basit süsleme kompozisyonu yer alır. Ayrıca Etiler okuluna sonradan getirilerek yerleştirilen B-İ-6 kazı envanter numaralı ve eserle benzer yaprak özeliklerine sahip İon başlığının yan yüzün yastık şeklindeki polsterde ki kök kısmında birbiriyle birleşen yatay yapraklarla bezenmiştir. Mızrak ucu şeklindeki bu yapraklarda herhangi bir detay işlemesine gidilmemiştir. Yan yüzünün orta elemanı olan balteus tek bir hacimli ve yuvarlak formlu bantla oluşturulmuştur.

4 numaralı İon kymation parçası (Katalog No. 4, Resim 11) 2004 yılındaki Preafurnium kazıları esnasında bulunmuştur. Hamamda kullanılmış olan İon başlığının echinus kısmına ait olabilecek yumurta dizisidir. İon başlığının ekhinusta 


\section{Tyana Roma Hamamı Kazılarında Ortaya Çıkan Sütun Başıı Parçaları}

yer alan ovolo profilinde genelde ion kymationu ile işlenmekteydi. Eserdeki görünüm itibarıyla bir ovolo profili görünümündedir. Eserde yumurtaların tam $U$ formunu almadığı ama oklarının yumurta arasında adeta eridiği gözlemlenir. Muhtemelen yerel bir atölyeden çıktığı tahmin edilen eserde yumurta kabukları etli yapılmış olup estetikten çok uzaktır. Özensiz ve yozlaşmış bir görüntüsü vardır. Kemerhisar'da Etiler ilkokuluna sonradan getirilerek yerleştirilen İon sütun başlığı incelendiğinde echinusunda bulunan ion kymationunun derin kanallı yumurta işlenişi tarihleme konusunda bize ilham vermektedir. B-İ-5 (Resim 12) kazı envanter numaralı bu başlı̆̆ın polster kısmına bakıldığında zengin bir süsleme yapıldığı görülür. Pulvinus üzerinde altı yapraktan oluşan kapalı palmet bezeği bulunmaktadır. Balteusta ise yaprak bezemeli geniş bir bant kullanılmıştır.

\section{b-Korinth Sütun Başlık Parçaları}

5 numaralı Korinth plaster başlık parçasının (Katalog No. 5, Resim 13) kabartama şeklinde yapıldığ 1 ve bitkisel bezekler zeminden $3 \mathrm{~cm}$ yüksekte kabartma şeklinde yapıldığı görülür. Abakus $5 \mathrm{~cm}$ uzunluğa sahiptir. En alt kısımda akanthus yaprağı, hemen üstünde caulis sapı yer alır, caulis sapının üzerinde helixler vardır ve caulis sapı abakus üzerinde bulunan abakus çiçeği ile birleşmektedir. Abakus üzerinde ise sırasıyla İon Kymationu (yumurta-ok) ve altında dil motifi yer almaktadır. Anadolu genelinde paye (plaster) başlıkları incelendiğinde eserde akanthus yapraklarının sade ve matkap işçiliğinde, helix ve abakus alanının daraldığını ve helixlerin kaba görüntüsünde olduğunu, abakus sapı ve abakus çiçeğinin sade görüntüde olduğu görülür. Bölge ve dekorasyon okulu farklılığı işçiliğe de yansımıştır. Abakus kısmının bezmeli oluşu Tyana' da bulunan korinth, kompozit başlıklar ve korniş bloklarında ki bölge farklılığından dolayı farklı bezmelerle işlendiği görülür (Berges ve Nolle, 2000, Taf. 77, Taf. 78, Taf. 79, Taf. 84, Taf. 85, Taf. 86, Taf. 87; Taf.89-Kat.134, Taf. 90, Taf. 91, Taf. 92; Taf. 92, Taf. 93).

6 numaralı akanthus yaprak parçası (Katalog No. 6, Resim 14) aşırı derecede tahribata uğramıştır. Eser muhtemelen hamamda kaplama parçası olarak kullanılmıştır. Akanthus yaprağı kabartma şeklinde zeminden $2.6 \mathrm{~cm}$ yüksektedir. Eser üç parçaya ayrılmıştır. Matkap işçiliği görülür. Yaprak damarları derin işlenmiş, yaprak uçları kıvrım yapmış ve uçları yuvarlaklaştırılmıştır. Yaprak uçları $\mathrm{C}$ formundan kapalı damla formuna yaklaşmıştır. Bu özellikler ile parça bize tarihleme konusunda yardımcı olmaktadır.

\section{c-Kompozit Sütun Başılı Parçası}

7 numaralı sütun başlık parçası (Katalog No. 7, Resim 15) dönemin (MS II.-III. yüzyıl) kompozit başlıklarını andırmaktadır. Başlık yukardan aşağıya doğru incelendiğinde İon kymationu (yumurta-ok), astragal (inci-boncuk) ve dalga motifi ile bezendiği görülür. Özellikle MS II. yüzyıldan sonra Anadolu'da oldukça popüler olan kompozit sütun başlığının kentlere göre kalathos ve abakuslerinin üst taraflarında yapılış farklılığı göstermektedir. Kompozit sütun başlıklarının bazılarında abakus kısımları da bezemeliydi. İon kymationunun $\mathrm{U}$ formunu alan 
yumurta kabukları ve düz işlenen ok uçları vardır. Tripolis hamamında bulunan friz parçasındaki yumurta-ok silmesiyle benzerlik göstermektedir. İon kymationu sırasının hemen altında yer alan astragal dizisine bakıldığında ise ince iplikçiklerle birbirlerine bağlı ve iki yassı bir uzun inci-boncuk yer aldığını görürüz. En alt kısımda kentte bulunan diğer mimari parçalarda çokça karşımıza çıkan dalga motifi vardir.

\section{d-Dil Motifli Bir Sütun Başlığı}

8 numaralı dil motifli sütun başlı̆̆ının (Katalog No. 8, Resim 16) kalathos üzeri dil motifiyle süslenmiştir. Şekil itibariyle sade bir görüntüye sahiptir. Ayrıca genel görünüm olarak aşırı tahribata uğramıştır. Abakus sade ve $10 \mathrm{~cm}$ uzunluğa sahip olup ekinus geçişinde $3 \mathrm{~cm}$ bir girinti yapmıştır. Ekinus ise $7 \mathrm{~cm}$ ve dile geçişte yine içeriye doğru $6 \mathrm{~cm}$ girinti yapmaktadır. Bezemeye bakıldığında ise derin bir oyguyla birbirlerinden ayrılan dillerin kaba bir görüntüsü vardır. Alt kısımları yarım ay biçimli tümsekler ile son bulmaktadır. Daha erken yani MS II.III. yüzyıl örneklerindeki kaba görüntüsü ve işçilik farklıyla ayrılır. Kentte bulunmuş olan kompozit başlık incelendiğinde (MS II. yüzyılın sonu III. yüzyılın başları) ise başlığın daha geç bir dönem yani MS IV.-V. yüzyıllara tarihlendiği görülür.

\section{3- Değerlendirme}

İncelediğimiz 7 adet başlık parçasının dönem olarak imar faaliyetlerinin artığı bir dönem olan MS II. yüzyılın sonu ve MS III. yüzyılın ilk yarısına tarihlenmektedir. Yalnızca 8 katalog numaralı dil motifli başlık parçasının daha geç bir döneme yani MS IV. yüzyıla tarihlendiği görülür.

İncelenen parçalardan 4 adet İon başlık parçasına ait volüt ve İon Kymation parçası, 2 adet Korinth başlık parçasına ait bir adet plaster parçası ve bir adet akanthus yaprak parçası ve bir adet kompozit başlık parçası olabilecek mimari elemanlar yer alır.

1 katalog numaralı İon volüt parçasında yalnızca volüt kıvrımlarının bir kısmı ve polster (yastık) kısmındaki bitkisel bezeklerin bir kısmı görülür. Yaprak işlenmişi sade ve kabartma şeklindedir. Eserin biçimsel olarak işlenişi basit bir görüntüye sahipken yozlaşma aşırı derecede değildir.

2 katalog numaralı volüt parçasında sadece volüt kısmı kalmıştır. Eser aşırı derecede tahribata uğramıştır. Eserde iki taraflı bir volüt sarmalı vardır.

3 katalog numaralı volüt parçasının volüt parçasının bir kısmı ve polster kısmının bir bölümü görünmektedir. 1 numaralı volüt parçasının polster ve volüt sarmalı işleniş olarak farklı bir yapısı vardır. Kemerhisar'da Etiler İlkokulu'na sonradan getirilerek yerleştirilen İon başlık parçasından yola çıkarak benzer bir başlık parçasına ait olabileceği kanısına varabiliriz. Söz konusu Etiler İlkokulu'nda bulunan ve B-İ-6 kazı envanter numaralı başlık parçasının polster kısmı ile 3 numaralı volüt parçasının polster kısmı benzer özellikler göstermektedir.

4 katalog numaralı İon Kymation parçası hamamın Praefurnnium yani

Külhan bölümünde bulunmuştur. Hamamda kullanılmış olan İon başlığının 


\section{Tyana Roma Hamamı Kazılarında Ortaya Çıkan Sütun Başlık Parçaları}

Echinus kısmının ovolo profiline ait olan İon Kymation parçasıdır. İon Kymation parçasının hamamın Praefurnium bölümünde bulunması burada kullanılan başlık parçalarının ya İon ya da Kompozit sütun başlığı olabileceğini göstermektedir. Ayrıca Kemerhisar'da Etiler İlkokuluna sonradan getirilerek yerleştirilen B-İ-5 kazı envanter numaralı İon sütun başlı̆̆ incelendiğinde echinusunda bulunan ion kymationunun derin ve kanallı işlenişi incelen eserle benzer özellikler göstermesi ve tarihleme konusunda bize ilham vermektedir.

5 numaralı Korinth plaster başlık parçası incelendiğinde diğer bölgelere göre biraz da olsa farklı özellikler görülmektedir. Eserde akanthus yapraklarının sade ve matkap işçiliğinde olduğu, helix ve abacus alanın daraldığ 1 , caulis sapı ve abacus çiçeğinin sade görüntüde olduğu görülür.

6 numaralı akanthus yaprağı muhtelen kaplama parçası olarak kullanılmıştır. Parça 2008 yılı kazı sezonunda ele geçmiştir. Akanthus yaprağı kabartma şeklinde yapılmıştır. Matkap işçilinde yapılan eserde damaların derin işlenişi ve yaprak uçlarının kıvrım yaptığı görülür.

7 numaralı kompozit bir başlığa ait olabilecek parçadır. Başlı̆ıın köşe kısmına ait olabilecek parçada volütün bir kısmı da görünmektedir. Başlığın abacus kısmında işlenen İon kymationu ve astragal sırası incelendiğinde. Öncelikle yumurtalarının kabuklarının $U$ formunda yozlaşmış işlenişi ve inci boncuklar arasında iplikçik kullanımı bizi Severus dönemi mimari özelliklerine götürmektedir.

Son olarak 8 katalog numaralı dil motifli sütun başlığı genel görünüm itibariyle sade bir görüntüye sahiptir. Eser komşu bölgelerde de rastlanan (Lykaonia, Psidia ve Phrygia) benzer örnekleri vasıtasıyla MS IV. - MS V. yüzyıllar arasına tarihlenir.

\section{4- Sonuc}

Tarihi Neolitik Çăg'a kadar geriye giden Tyana kenti konumu itibariyle sürekli olarak iskan görmüş bir yerleşmedir. Gerek madenlerin bol olması gerek doğal şartlarıyla ideal bir yerleşme görünümündeki kent en erken yazılı kayıtlarda adı Tuwanuwa olarak görünmektedir. Boğazköy çivi yazılı tabletlerde geçen bu isimden yola çıkarak burada yerleşenlerin ilk olarak Luwi kökenli olduğu düşünülmektedir.

Hititlerin yıkılışının ardından Geç Hitit Çağı'nda bölgede yerel beylikler kurulmuştur. Bu dönemde yerel bir beylik olana Tuwana/Tuhana Krallığı bölgede etkin rol oynamıştır. Özellikle kral Warpalawas döneminde en iyi dönemini yaşayan krallık bölgede de çeşitli eserler bırakmıştır.

Daha sonraki dönemlerde sırasıyla önce Asur, Pers, Hellenistik krallıklar ve Roma himayesine girmiştir. İște günümüzde ayakta kalan Roma Havuzu, Su Kemerleri ve Roma Hamamı MS II. yüzyılın sonu MS III. yüzyılın ilk yarısında yani imar faaliyetlerinin arttığı dönemde yapılmışıı. İmar faaliyetlerinin artmasının nedeni Roma imparatorlarının kente verdiği önemden dolayıdır. Kent hem güneyde Sasanilere hem de Parthlara karşı saldırıda kilit bir noktadadır. Kente verilen önemin as1 sebebi ise Pytogorasc1 bir filozof olan Apollonius'un 
memleketi olmas1 nedeniyledir. Hadrianus ve daha sonra Severuslar Apollonius'a önem vermiş ve onun adına kentte çeşitli fonksiyonlarda kamu yapıları inşa ettirmişlerdir.

Hamam yapısı imar faaliyetlerinin attığ bir dönemde yani MS II. yüzyılının sonu III. yüzyılın ilk yarısında inşa edildiği düşünülmektedir. Yapılan kazılarda ortaya çıkarılan ve çalışmamızda işlenen 7 adet sütun başlık parçasının genel olarak MS III. yüzyıla tarihlendiği görülmüştür. Ayrıca hamamda farklı başlık tiplerinin kullanılmış olması hamamın iki katlı olabileceği görüşünü ortaya çıkarmaktadır. Başlıkların kaliteli mermerden yapılması ve dönemin sanat üslubuna özgü yapılmaları da tarihleme konusunda bize yardımcı olmaktadır. 8 katalog numaralı başlığın varlığından yola çıkarak da daha sonraki dönemlerde hamamın tamir edildiği ya da başka bir amaçla kullanıldığı düşünülmektedir.

\section{KATALOG}

Kat. No: 1

Mimari Eleman Adı: İon Volüt Parçası

Malzeme: Mermer

Ölçüleri: En: $9 \mathrm{~cm}$

Boy: $19 \mathrm{~cm}$

Yükseklik: $24 \mathrm{~cm}$

Tanım: Tyana Roma Hamamı kazılarında bulunmuş volüt parçasıdır. Kazı ekibi tarafından esere H-8 envanter numarası verilmiştir. Eser aşırı derecede tahribata uğramıştır. Parçada volüt kıvrımları ve polster (yastık) kısmında ki bitkisel yaprak bezemesi görünmektedir. Yaprak $1.7 \mathrm{~cm}$ kabartma yüksekliğine sahiptir. Öncelikle yaprak işlenişindeki sadelik göze çarpar. Yapraklar muhtemelen balteustan çıkıp volütlere doğru gelmiştir. Yaprak damarı tek çizgi halinde ve yaprağın ucuna doğru gelmektedir. Mızrak ucu şeklindeki bu yapraklarda herhangi bir detay işlenmesine gidilmemiştir. Anadolu genelinde Severuslar dönemine tarihlenen sütun başlıklarının birçoğunda olduğu gibi söz konusu eserde süslemelerdeki biçimsel bozulmalara paralel olarak polsterde yüzeysel olarak işlenmiş basit süsleme kompozisyonu yer alır. Ayrıca Kemerhisar'da Etiler okulunda sonradan getirilerek yerleştirilen B-İ-6 kazı envanter numaralı ve eserle benzer yaprak özeliklerine sahip İon başlığının yan yüzün yastık şeklindeki polster kısmında yer alan kök kısmında birbirine birleşen yatay yapraklarla bezenmiştir. Mızrak ucu şeklindeki bu yapraklarda herhangi bir detay işlemesine gidilmemiştir. Yan yüzünün orta elemanı olan balteus tek bir hacimli ve yuvarlak formlu bantla oluşturulmuştur ve incelenen eserle benzer özellikler gösterir.

Literatür: Psidia örneği için bkz.: Alp, 2006: 38, Lev. 14a-b - Kat.16.: Lev.16a-b Kat.19.: Lev.16c-d - Kat.20.; Benzeri örnekler için bkz.: Çelik, 2019: 76.; Beykan, 2004: 106, Kat. 27e.: Kat. 55c; Herrmann, 1988: Pl. CXIV-Fig. 260.; Bingöl, 1980: Lev. 38, Kat. 293. Tyana kentinde bulunan diğer İon başlıkları için bkz.: 


\section{Tyana Roma Hamamı Kazılarında Ortaya Çıkan Sütun Başıı Parçaları}

Berges ve Nolle, 2000: Taf. 88-Kat.127; Taf. 89-Kat.131. Konya müzesi örnekleri için bkz.: Mert, 2002: Kat. 5, Res.15-16. Afyon Müzesi örneği için: Bingöl, 1980: Lev. 32, Kat. 1.

Kat. No: 2

Mimari Eleman Adı: Volüt Parçası

Malzeme: Mermer

Ölçüleri: En: $8 \mathrm{~cm}$

Boy: $7 \mathrm{~cm}$

Yükseklik: $9 \mathrm{~cm}$

Tanım: Tyana Roma Hamamı kazılarında bulunmuş volüt parçası. Kazı ekibi tarafından esere H-10 envanter numarası verilmiştir. Eser aşırı derecede tahribata uğramıştır. Kompozit ya da İon sütun başlı̆̆ına ait olabilecek volüt parçasıdır. Chitham'ın Antik mimarlıkta düzenleri ele aldığı kitabında İonik Başlık I olarak tanımladığ başlıktan yola çıkarak İonik bir sütun başlığına ait olabileceği kanısına varabiliriz. Ayrıca kompozit sütun başlıklarında da gördügümüz akanthus ve İon volütünün bir arada kullanımından yola çıkarak eserde iki taraflı bir volüt sarmalının olduğu da söylenebilir. MS I. yüzyıldan sonra şekillenmeye başlayan Kompozit sütun başlıkları MS II. yüzyılın ortalarından itibaren yoğun olarak kullanılmıştır.

Literatür: Kompozit sütun başlıklarının gelişimi için bkz.: Başran, 1999. MS II.III. yüzyıl Tyana korint başlık gelişimi için bkz.: Berges ve Nolle, 2000: Taf. 90, Taf. 91, Taf. 92-Kat.136, Taf. 93. Tyana İon Başlıkları için bkz.: Berges ve Nolle, 2000: 152, Taf. 88,1-2-Kat. 127, Taf. 89, Kat.131. Chitham'ın İonik Başlık I ve Kompozit başlığı için bkz.: İonik Başlık I: Chitham, 2005: 77, Kompozit Başlık: Chitham, 2005: 99. Burdur Müzesi'nde bulunan dört yüzlü İonik sütun başlığı için bkz.: Alp, 2013: 64, Fig. 8-9-10; Konya Müzesi'nde bulunan İon sütun başlıkları için bkz. Mert, 2002: 247-269; MS V.-VI. yüzyıl volüt karşılaştırmaları için bkz.: Mango, 1968: Fig.160; Maqurie, 1987: Fig.6; Dasssmann vd., 2004: Fig. 16.

Kat. No: 3

Mimari Eleman Adı: İon Volüt Parçası

Malzeme: Mermer

Ölçüleri: En: $8 \mathrm{~cm}$

Boy: $14 \mathrm{~cm}$

Yükseklik: $15 \mathrm{~cm}$

Tanım: Tyana Hamam kazılarında bulunmuş volüt parçası. Eser aşrı derecede tahribata uğramıştır. 2003 yılı kazı sezonunda ve hamamın Legnaia (Odunluk) bölümünde bulunmuş bir parçadır. Kazı ekibi tarafindan esere H-93 envanter numarası verilmiştir. Volüt ve polster kısmı görülmektedir. Öncelikle yaprak işlenişindeki sadelik göze çarpar. Polster kısmındaki yapraklar muhtemelen balteustan çıkıp volütlere doğru gelmiştir. Mızrak ucu şeklindeki bu yapraklarda herhangi bir detay işlenmesine gidilmemiştir. Anadolu genelinde Severuslar dönemine tarihlenen sütun başlıklarının birçoğunda olduğu gibi söz konusu eserde 
süslemelerdeki biçimsel bozulmalara paralel olarak polsterde yüzeysel olarak işlenmiş daha basit süsleme kompozisyonu yer alır. Ayrıca Kemerhisar'da Etiler okuluna sonradan getirilerek yerleştirilen B-İ-6 kazı envanter numaralı ve eserle benzer yaprak özeliklerine sahip İon başlığının yan yüzün yastık şeklindeki polsterde ki kök kısmında birbiriyle birleşen yatay yapraklarla bezenmiştir. Mızrak ucu şeklindeki bu yapraklarda herhangi bir detay işlemesine gidilmemiştir. Yan yüzünün orta elemanı olan balteus tek bir hacimli ve yuvarlak formlu bantla oluşturulmuştur.

Literatür: Psidia örneği için bkz.: Alp, 2006: 38, Lev. 14a-b - Kat.16.: Lev.16a-b Kat.19.: Lev.16c-d - Kat.20.; Benzeri örnekler için bkz.: Çelik, 2019: 76.; Beykan, 2004: 106, Kat. 27e.: Kat. 55c; Herrmann, 1988: Pl. CXIV-Fig. 260.; Bingöl, 1980: Lev. 38, Kat. 293. Tyana kentinde bulunan diğer İon başlıkları için bkz.: Berges ve Nolle, 2000: Taf. 88-Kat.127; Taf. 89-Kat.131. Konya müzesi örnekleri için bkz:: Mert, 2002: Kat. 5, Res.15-16. Afyon Müzesi örneği için: Bingöl, 1980: Lev. 32, Kat. 1.

Kat. No: 4

Mimari Eleman Adı: İon Kymation Parçası

Malzeme: Mermer

Ölçüleri: En: $21 \mathrm{~cm}$

Boy: $8 \mathrm{~cm}$

Yükseklik: $7.2 \mathrm{~cm}$

Tanım: Tyana Hamam kazılarında bulunmuş İon Kymation parçası. Eser aşrı derecede tahribata uğramıştır. 2004 yılı kazı sezonunda ve hamamın Praefurnium (Külhan) bölümünde bulunmuş bir parçadır. Kazı ekibi tarafından ise esere H-132 envanter numarası verilmiştir. Bir İon başlığına ait olabilecek parçadır. İon başlığının echinusta yer alan ovolo profilinde genelde İon kymationu ile işlenmekteydi. Eserdeki görünüm itibarıyla bir ovolo profili görünümündedir. Eserde yumurtaların tam U formunu almadığı ama okların yumurta arasında adeta eridiği gözlemlenir. Muhtemelen yerel bir atölyeden çıktığı tahmin edilen eserde yumurta kabukları etli yapılmış olup estetikten çok uzaktır. Özensiz ve yozlaşmış bir görüntüsü vardır. Kemerhisar'da Etiler İlkokuluna sonradan getirilerek yerleștirilen B-İ-5 kazı envanter numaralı İon sütun başlı̆̆ 1 incelendiğinde echinusunda bulunan ion kymationunun derin kanallı yumurta işlenişi tarihleme konusunda bize ilham vermektedir.

Literatür: Benzer örnekler için bkz.: Kökmen-Seyirci, 2016: Lev.5-Kat.8; Alp, 2013: 67-Fig.19; Mert, 2002: 249,Kat.2-Res.5-8.

Kat. No: 5

Mimari Eleman Adı: Korinth Plaster Başlık Parçası

Malzeme: Mermer

Ölçüleri: En: $25 \mathrm{~cm}$

Boy: $26 \mathrm{~cm}$

Yükseklik: $10 \mathrm{~cm}$ 


\section{Tyana Roma Hamamı Kazılarında Ortaya Çıkan Sütun Başıı Parçaları}

Tanım: Tyana Roma Hamamı kazılarında bulunmuş olan Korinth plaster (paye) başlığıdır. Kazı ekibi tarafından esere H-13 envanter numarası verilmiştir. Eser aşırı derecede tahribata uğramıştır. Kabartama şeklinde yapılan bitkisel bezekler zeminden $3 \mathrm{~cm}$ yüksekte kabartma şeklinde yapılmıştır. Abakus $5 \mathrm{~cm}$ uzunluğa sahiptir. En alt kısımda akanthus yaprağı, hemen üstünde caulis sapı vardır. Caulis yaprağının üzerinde helixler çıkar. Helixlerin arkasından abakus çiçeğinin sapı geçmekte ve abakus üzerinde bulunan abakus çiçeği ile birleşmektedir. Abakus üzerinde ise sirasiyla dil motifi ve yumurta-ok (İon Kymationu) yer almaktadır. Anadolu genelinde plaster (paye) başlıkları incelendiğinde söz konusu eserde akanthus yapraklarının sade ve matkap işçiliğinde, helix ve abakus alanının daraldığı, caulis sap1 ve abakus çiçeğinin sade görüntüde olduğu görülür. Bölge ve dekorasyon okulu farklılığı işçiliğe de yansımıştır. Abakus kısmının bezemeli oluşu Tyana'da bulunan Korinth, Kompozit başlıklar ve korniş bloklarında ki bölge farklılığından dolayı farklı bezmelerle işlendiği görülür.

Literatür: Benzerleri ile karşılaştırmak için bkz.: Sagalassos E1 Bazilikası plaster başlığ için bkz.: Vandeput, 1997: 83, Pl. 36.4, Pl. 37.1; Ayrıca plaster başlıkların gelişimini görmek için bkz.: Perge Agorası'ndaki korinth plaster başlıkları; Pisida Antiocheia'sı Augustus Tapınağı korinth plaster başlıkları; Pergamon Kızıl Avlu plaster başlıkları; Aphrodisias Hadrian Hamamları korinth plaster başlığı için bkz.: Koçel-Erdem, 1996: 32, Lev.11.1; Tyanada bulunana korith, kompozit başl1klar ve korniş blokları için bkz.: Berges ve Nolle 2000: Korniş blokları: Taf. 77, Taf. 78, Taf. 79, Taf. 84, Taf. 85, Taf. 86, Taf. 87; Korinth başlıkları: Taf.89-Kat.134, Taf. 90, Taf. 91, Taf. 92; Kompozit başlıklar: Taf. 92, Taf. 93; Erken Severus Dönemi plaster başlık karşılaştırması için bkz.: Perge Tiyatro Sahne binası; Türkmen, 2007: 142, Kat. 52, Kat.53, Kat. 54, Kat. 55, Kat.56, Kat. 57; Rhodiapolis örneği ile karşılaştırmak için bkz.: Kökmen-Seyirci, 2016: 130, Lev. 22, Kat.56.

Kat. No: 6

Mimari Eleman Adı: Akanthus Kaplama Parçası

Malzeme: Mermer

Ölçüleri: En: $12.5 \mathrm{~cm}$

Boy: $3.5 \mathrm{~cm}$

Yükseklik: $4 \mathrm{~cm}$

Tanım: Tyana Hamam kazılarında bulunmuş akanthus yapraklı kaplama parçası. Eser aşrı derecede tahribata uğramıştır. 2008 yılı kazı sezonunda bulunmuş bir parçadır. Kazı ekibi tarafından esere H-89 envanter numarası verilmiştir. Akanthus yaprağı kabartma şeklinde zeminden $2.6 \mathrm{~cm}$ yüksektedir. Eser üç parçaya ayrılmıştır. Matkap işçiliği görülür. Yaprak damarları derin işlenmiş, yaprak uçları kıvrım yapmış ve uçları yuvarlaklaştırılmıştır. Yapraklar C formundan kapalı damla formuna yaklaşmıştır.

Literatür: Benzerleri ile karşılaştırmak için bkz.: Sagalassos E1 Bazilikası plaster başlığı için bkz.: Vandeput, 1997: 83, Pl. 36.4, Pl. 37.1; Ayrıca plaster başlıkların gelişimini görmek için bkz.: Perge Agorası'ndaki korinth plaster başlıkları; Pisida Antiocheia'sı Augustus Tapınağı korinth plaster başlıkları; Pergamon Kızıl Avlu 
plaster başl1kları; Aphrodisias Hadrian Hamamları korinth plaster başlığ için bkz.: Koçel-Erdem, 1996: 32, Lev.11.1; Tyanada bulunana korith, kompozit başliklar ve korniş blokları için bkz.: Berges ve Nolle 2000: Korniş blokları: Taf. 77, Taf. 78, Taf. 79, Taf. 84, Taf. 85, Taf. 86, Taf. 87; Korinth başlıkları: Taf.89-Kat.134, Taf. 90, Taf. 91, Taf. 92; Kompozit başlıklar: Taf. 92, Taf. 93, Erken Severus Dönemi plaster başlık karşılaştırması için bkz.: Perge Tiyatro Sahne binası; Türkmen, 2007: 142, Kat. 52, Kat.53, Kat. 54, Kat. 55, Kat.56, Kat. 57; Rhodiapolis örneği ile karşılaştırmak için bkz.: Kökmen-Seyirci, 2016: 130, Lev. 22, Kat.56.

\section{Kat. No: 7}

Mimari Eleman Adı: Kompozit Başlık Parçası

Malzeme: Mermer

Ölçüleri: En: $20 \mathrm{~cm}$

Boy: $16 \mathrm{~cm}$

Yükseklik: $12 \mathrm{~cm}$

Tanım: Tyana Roma Hamamı kazılarında bulunmuş sütun başlığının (kompozit?) abakus kısmına ait parça. Kazı ekibi tarafindan esere H-7 envanter numarası verilmiştir. Eser aşırı derecede tahribata uğramıştır. Başlığın köşe kısmına ait olabilecek parçada volütün bir kısmı da görünmektedir. Aşağıdan yukarıya doğru bakıldığında dalga motifi, inci-boncuk (astragal) ve yumurta-ok (Ion Kymationu) ile bezenmiştir. Ö̈zellikle MS II. yüzyıldan sonra Anadolu' da oldukça popüler olan Kompozit sütun başlığının kentlere göre kalathos ve abakuslerde yapılış ve bezeme farklılığı görünmektedir. Ayrıca, Kompozit sütun başlıklarının bazılarında abakus kısımları da bezeliydi. İon kymationunda $U$ formunu aldığı yumurta kabukları ve düz işlenen ok uçları vardır. Tripolis hamamında bulunan friz parçasındaki yumurta-ok silmesiyle benzerlik göstermektedir. Yumurta-ok (İon kymationu) sırasının hemen altında yer alan astragal dizisine bakarsak eğer ince iplikçiklerle birbirlerine bağlı ve iki kısa bir uzun inci-boncuk yer aldığını görürüz.

Literatür: Anadolu kompozit başlıkların gelişimi için bkz.: Başaran, 1999: 1-84; Nassar, 2008: 3-20. Kibyra kompozit başlıklar için bkz.: Kaya, 2011: 20-21 Kat. 18-19. Yumurta-Ok (İon Kymationu) gelişimi için bkz.: Karaosmanoğlu, 1996: 5156. Rhodiapolis kompozit başlıklar için bkz.: Kökmen-Seyirci, 2016: 133-140. Kilikia Bölgesi kompozit başlıkları için bkz.: Kaplan, 2013: 71.; Tripolis örneği için bkz.: Daşbacak, 2017: 98.

Kat. No: 8

Mimari Eleman Adı: Dil Motifli Başılık Parçası

Malzeme: Mermer

Ölçüleri: En: $30 \mathrm{~cm}$

Boy: $45 \mathrm{~cm}$

Yükseklik: $32 \mathrm{~cm}$

Tanım: Tyana Roma Hamamı kazılarında bulunmuş sütun başlık parçası. Kazı ekibi tarafından esere $\mathrm{H}-1$ envanter numarası verilmiştir. Abakus ve echinusu geniş silme şeklindedir. Kalathos üzeri dil motifiyle süslenmiştir. Şekil itibariyle sade bir 


\section{Tyana Roma Hamamı Kazılarında Ortaya Çıkan Sütun Başıı Parçaları}

görüntüye sahiptir. Ayrıca genel görünüm olarak aşırı tahribata uğramıştır. Abakus sade ve $10 \mathrm{~cm}$ uzunluğa sahip olup echinus geçişinde $3 \mathrm{~cm}$ bir girinti yapmıştır. Echinus ise $7 \mathrm{~cm}$ 'dir ve dile geçişte yine içeriye doğru $6 \mathrm{~cm}$ girinti yapmaktadır. Bezemeye bakıldığında ise derin bir oyguyla birbirlerinden ayrılan dillerin kaba bir görüntüsü vardır. Alt kısımları yarım ay biçimli tümsekler ile son bulmaktadır. Daha erken örneklerinden (Trajan-Hadrian Dönemi Anadolu kompozit sütun başlıkları) kaba görüntüsü ve iş̧̧ilik farklıyla ayrılır. Kentte bulunmuş olan kompozit başlık incelendiğinde (MS II. yüzyılın sonu III. yüzyılın başları) ise başlığın Erken Bizans Dönemine gittiği görülür.

Literatür: Trajan-Hadrian Dönemi dil süslemeli kompozit başlıklar için bkz.: Heilmeyer, 1970:104, Taf. 39.1; Thür, 1989:108, Abb.167-169; Koçel Erdem, 1996:182; İdil, 1976: 18, Lev. 9.1.; Psidia Bölgesi dil süslemeli kompozit başlıklar için bkz.: Alp, 2006; 61-67, Lev.22. Ayrıca Tyana'da bulunmuş olan kompozit başlık için bkz.: Berges ve Nolle, 2000: 159, Taf. 92, Kat. 149. Dil süslemeli Friz örnekleri için bkz.: Anabolu, 1992, 1-10; Vandeput, 1997: 250, Pl.17.3, Pl. 48.1-2; Baldıran ve Gider, 2008: 118-120. Kilikya Bölgesi dil süslemeli mimari parçalar için bkz.: Kaplan, 2013: 161-165. Eserin Lykaonia örneği için bkz.: Temple, 2013, 133-134., Eserin Psidia örneği için bkz: Alp, 2006; 60,Lev.26-Kat.47b; Eserin Hadrianoupolis örneği için bkz.: Cumalığlu, 2011: 233-234, Kat. 156-157; Ayrıca benzer örnekler için bkz.: Eyice, 1972: Fig. 22, 29-32; Tezcan, 1989: Fig. 170171, Fig. 473; Parman, 2002: Fig. 140, Fig. 157, Fig. 158, Fig. 161, Fig. 167, Fig. 168, Fig. 183; Peschlow vd., 2002: Fig. 17/c-e, 18/a; Doğan, 2005: Fig. 5; Niewöhner, 2007: Fig. 35-44; Hakan, 2009: Fig. 1-10.

\section{KAYNAKÇA}

Akurgal, E. (2002). Anadolu'nun Kültür Tarihi. İstanbul: Asır Matbaacılık Ltd. Şti. Başaran, C. (1999). Anadolu Mimari Bezemeleri, Roma Çă̆ı Lotus-Palmet Örgesi. Erzurum: Erzurum Fen-Edebiyat Fakültesi Yayını.

Berges, D. ve Nolle, J. (2000). Tyana: Archaologisch-Historische Untersuchungen zum Südwestlichen Kappadokien. 1-2, Bonn: Habelt.

Berges, D. (2002). Tyana in Kappadokien: Von der Hethitischen Residenz zur Gräco-Römischen Colonia, AW, (33) 2, s.177-187.

Beykan, M. (2004). Prokennesosta Bulunan İon Sütun Başlıkları Yerel Mermer Ocaklarında Biçimlendirilmesi ve İhracatı (Yayınlanmamış Doktora Tezi). İstanbul Üniversitesi, İstanbul.

Bingöl, O. (1980). Das Ionische Normalkapitell in Hellenistischer und Römischer Zeit in Kleinasien. İstanbul:Verlag Ernst Wasmuth Tübingen.

Birley, A. R. (2000). Hadrian to the Antonines, The Accession of Hadrian. The Cambridge Ancient History, 9, The High Empire, A.D. 70-192, (Ed.: Bowman, A.K., Garnsay, P., Rathbone, D.), Cambridge, s.132-136.

Börker C. ve Berges D. (1996). Tyana-Survey 1995, AST, (14/1), s.17-26.

Burton, E. (2005). Tyana (Ed.: Herbermann, C.G.). The Catholic Encyclopedia, The Catholic Encyclopedia An International Work of Reference on The Constitution, Doctrine, Discipline, And History of the Catholic Church, 15, 
New York, s.259.

Chitham, R. (2005). The Classsical Orders of Architecture. Oxford: Architectural Press.

Cramer, J. A. (1832). A Geographical and Historical Description of Asia Minor: With a Map. Oxford.

Daşbacak, C. (2017). Tripolis Roma Hamamı (Büyük Hamam). (Ed: Duman, B.). Tripolis Araştırmaları. İstanbul: Ege Yayınları, s.91-99.

Eck, W. (2000). Government And Civil Administration, Emperor: Senate and Magistrates. The Cambridge Ancient History, 11, The High Empire, A.D. 70-192, (Ed.: Bowman, A. A., Garnsay, P., Rathbone, R.), Cambridge, s.214-238.

Elalmış, A. (2007). Köşk Höyük Kazı Alanının Jeofizik Yöntemler ile Araştırılması (Yayınlanmamış Yüksek Lisans Tezi). Ankara Üniversitesi, Ankara.

French, D. (1981). Roma Çă̆ında Küçük Asya'daki Yollar ve Mil Taşları, Fasikül 1: Hacı Yolu. Ankara: British Institute of Archaeology at Ankara.

Ganschow, T. (2018). Münzen von Kappadokien: Sammlung Henseler, 1-2, Gephyra 5, İstanbul.

Herrmann, J. (1988). The Ionic Capital in Late Antique Rome (Vol. 56), Bretschneider Giorgio.

Hild, F. (1977). Das Byzantinische Strassensystem in Kappadokien. TIB, 131(2), Wien.

Jones, A. H. M. (1998). Cities of the Eastern Roman Provinces. Oxford.

Kaplan, D. (2013). Kilikia Bölgesi Roma Imparatorluk Dönemi Mimari Süslemeleri (Yayınlanmamış Doktora Tezi). Mersin Üniversitesi, Mersin.

Koçel-Erdem, Z. (1996). Anadolu'da Hadrianus Dönemi Mimari Bezemeleri (Yayınlanmamış Doktora Tezi). İstanbul Üniversitesi, İstanbul.

Kökmen-Seyirci, H. (2016). Rhodiapolis Antik Kenti Mimari Bezemeleri (Yayınlanmamış Doktora Tezi). Akdeniz Üniversitesi, Antalya.

Lloyd, S. (1998). Türkiye’nin Tarihi (Çev.: Varinlioğlu, E.). Ankara: Tübitak Yayınlar1.

Magie, D. (1950) . Roman Rule in Asia Minor to the End of the Third Century after Christ, 1-2, New Jersey: Princeton University Press.

Mert, İ. H. (2002). Konya Arkeoloji Müzesi’ndeki İon Başlıkları. Selçuk Üniversitesi Sosyal Bilimler Enstitüsü Dergisi, 8, s.247-269.

Öztan, A. (2005). Birinci Dönem Köşkhöyük-Niğde Kazl Buluntularının Değerlendirilmesi ve Stratigrafik Kontrolü. Ankara: Ankara Üniversitesi Bilimsel Araştırma Projeleri.

Philostratus (). De Vita Apollonii Tyanei Libri Octa: The Life of Apollonius of Tyana (Çev. F.C. Coynbeare 1912). London.

Plinius, Naturalis Historia, The Natural History, III-VII (Çev. H. Rackham 1855). London: Harvard Universty Press.

Robert, L. (1946). Hellenica Recueil D’Épicraphie De Numismatique Et D’Antiquités Grecques. 2, Paris. 


\section{Tyana Roma Hamamı Kazılarında Ortaya Çıkan Sütun Başıı Parçaları}

Rosada, G. ve Lachin, M.T. (2008). Excavations 2007 at Tyana. KST, 30(3), s.116.

Rosada, G. ve Lachin, M.T. (2010). Excavations at Tyana/Kermerhisar 2009. KST, 32(3), s.196-215.

Rosada, G. ve Lachin, M.T. (2011). Excavations at Tyana/Kemerhisar, 2010 Achbishop Patrikios's Church. KST, 33(3), s.77-96.

Ruge, W. (1948). Tyana. RE, 7, (A-2), s.1630-1635.

Sevin, V. (1998). Tarihsel Coğrafya: Güzel Atlar Ülkesi Kapadokya (Ed. M, Sözen). İstanbul: Ayhan Şahenk Vakf1 Yayınları.

Strabon, Antik Anadolu Coğrafyası. Geographika: XII-XIII-XIV (Çev. A. Pekman 2000). İstanbul: Arkeoloji ve Sanat Yayınları.

Şener, H. H. (2019). Tyana Kenti’nin Roma Impratorluk Dönemi Sikke Basımı. Tyana Kazı ve Araştırmaları I (Ed.: Doğanay, O.), İstanbul: Arkeoloji ve Sanat Yayınları, s. 121-153.

Tekin, O. (2016). Eski Yunan ve Roma Tarihine Giriş. İstanbul: İletişim Yayınları.

Texier, C. (2002). Küçük Asya Coğrafyası I-II-III: Tarihi ve Arkeolojisi (Çev. Suad, A.). İstanbul: Amire Matbaası.

Türkmen, M. (2007). Pamphylia ve Kilikia'da Severuslar Dönemi Mimari Bezemesi (Yayınlanmamış Doktora Tezi). İstanbul Üniversitesi, İstanbul.

Vandeput, L. (1997). The Achitectural Decaration Roman Asia Minor: Sagalassos a Case Study. Leuven: Brepols Publishers.

Vitruvius. Mimarlık Üzerine On Kitap (Çev. S. Güven 2005). İstanbul: Şevki Vanlı Mimarlık Vakfı Yayınları. 
Tahir GÜRKAN - Osman DOĞANAY

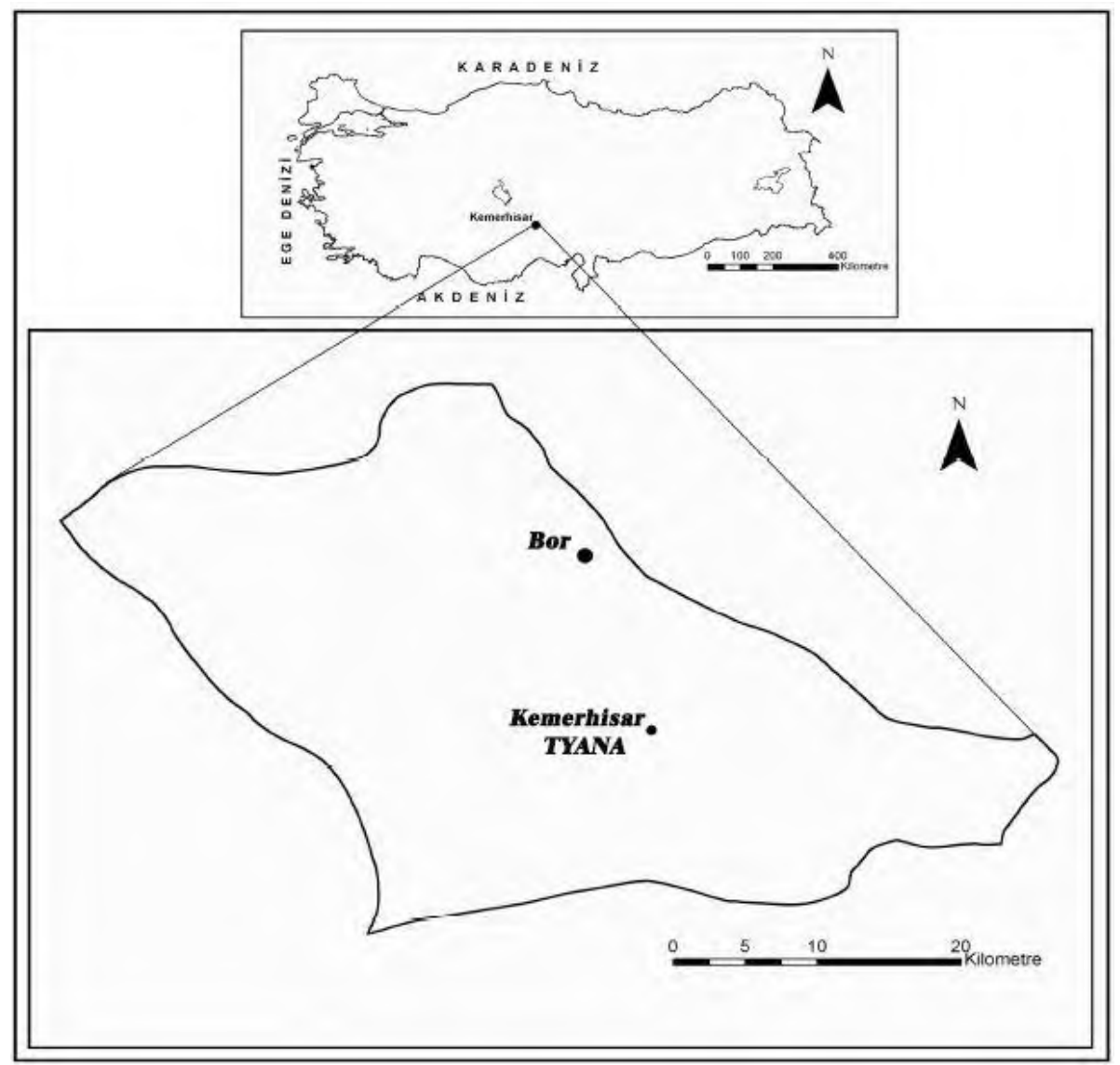

Resim 1 
Tyana Roma Hamamı Kazılarında Ortaya Çıkan Sütun Başık Parçaları

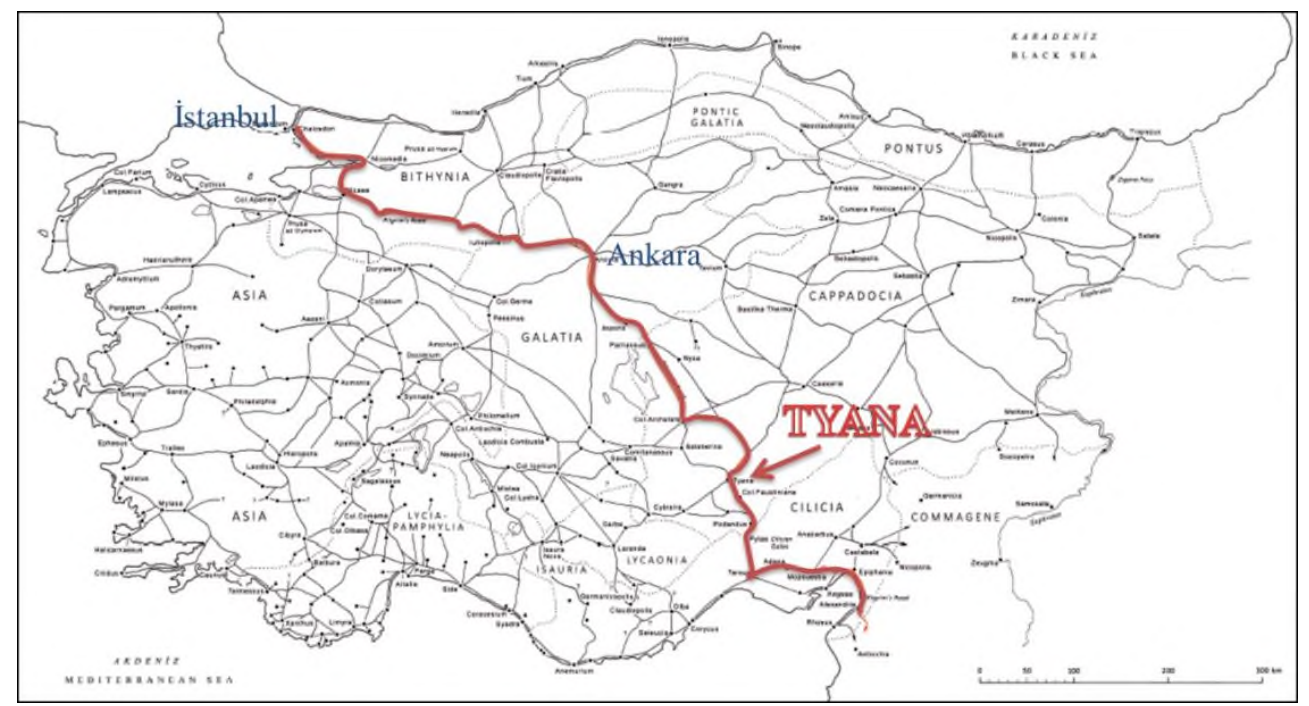

Resim 2

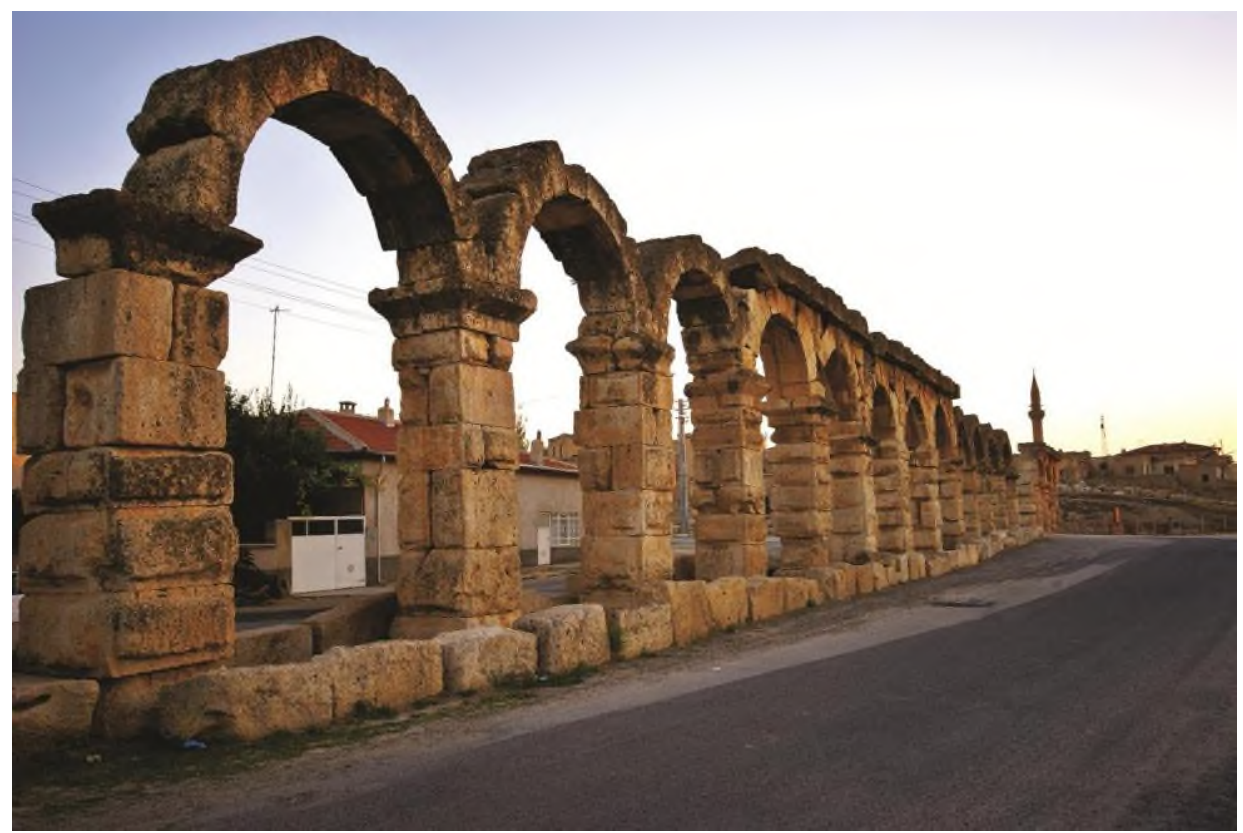

$\operatorname{Resim} 3$ 
Tahir GÜRKAN - Osman DOĞANAY

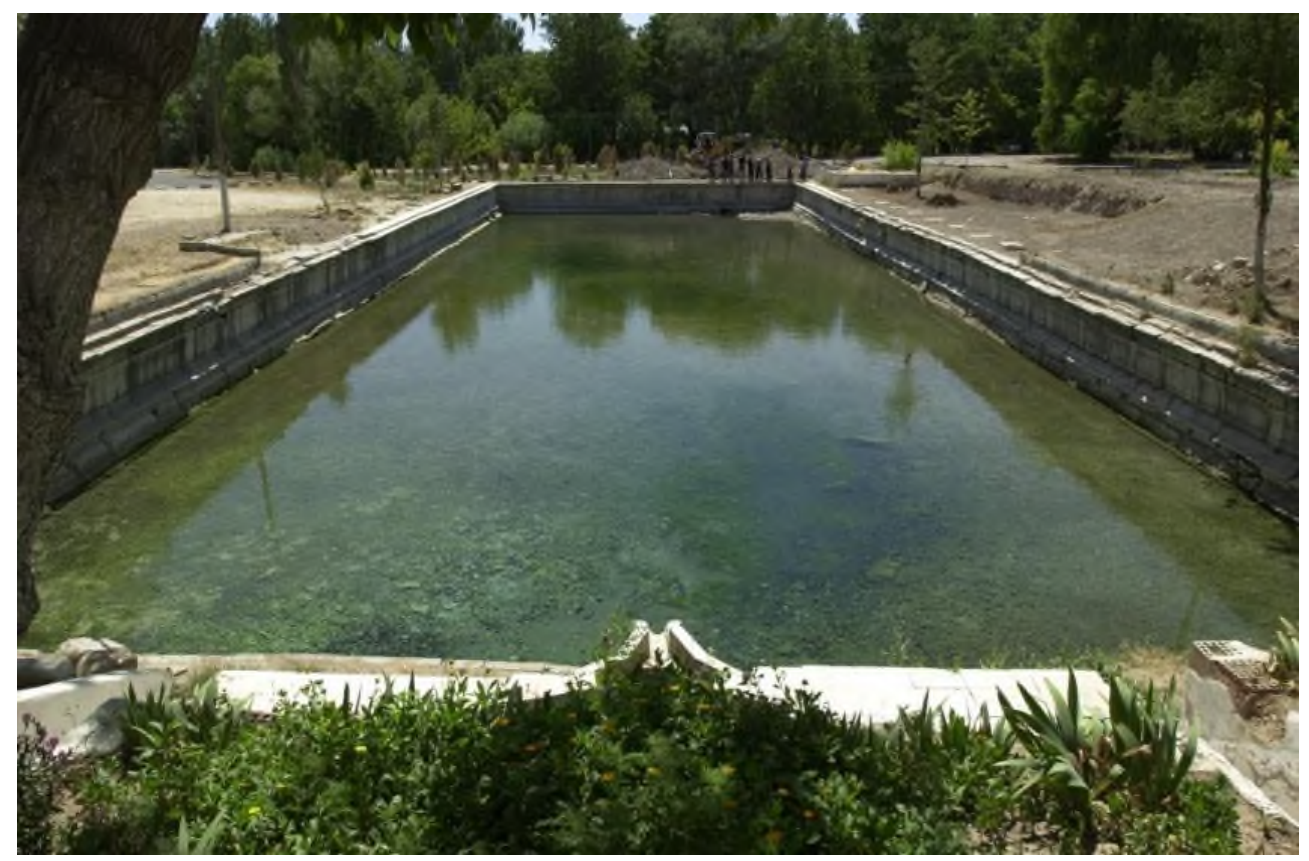

$\operatorname{Resim} 4$ 
Tyana Roma Hamamı Kazılarında Ortaya Çıkan Sütun Başlık Parçaları

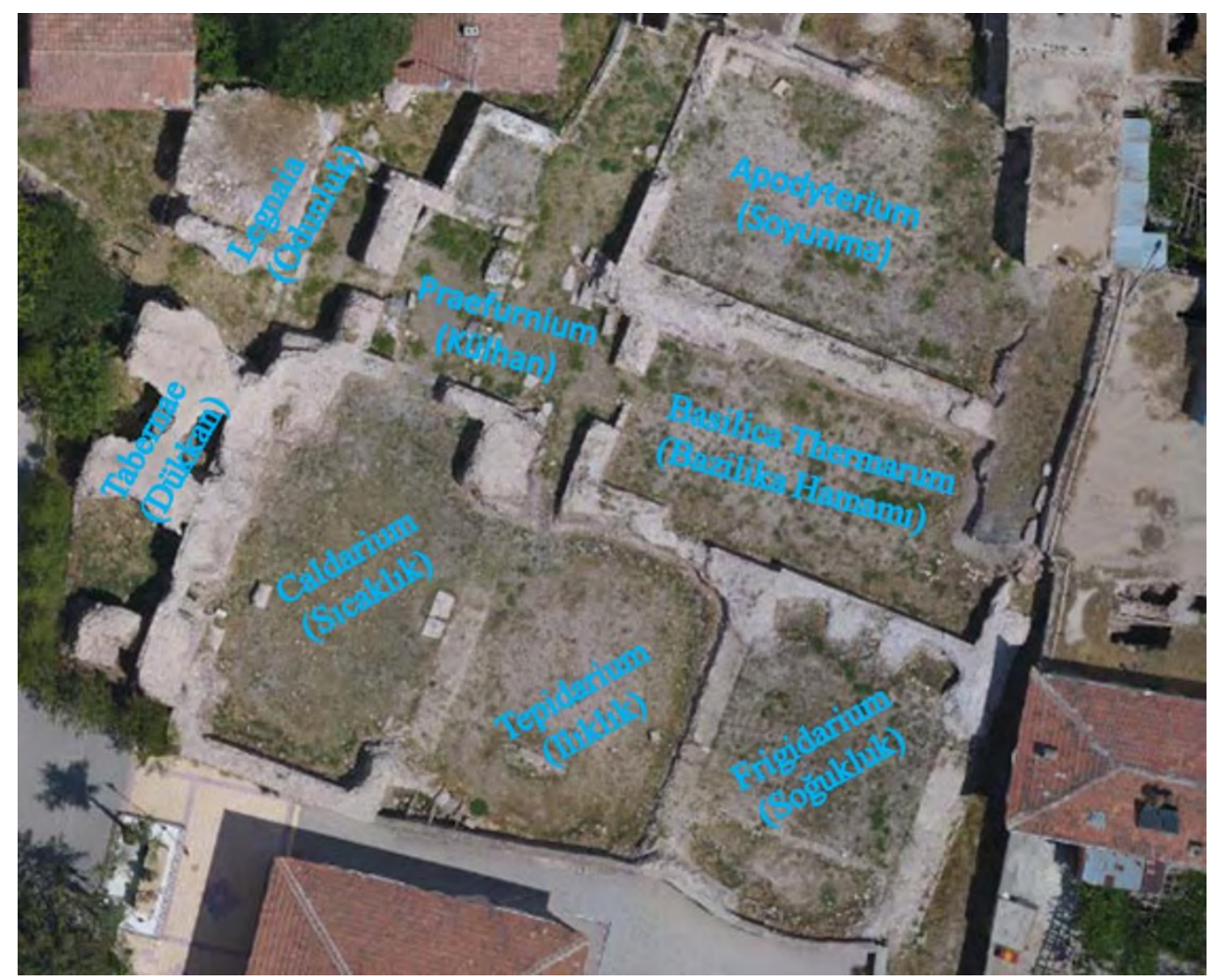

\section{Resim 5}

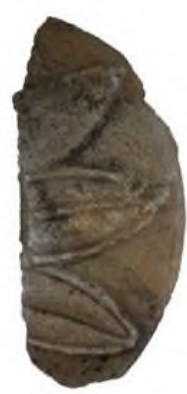

0

10

$20 \mathrm{~cm}$

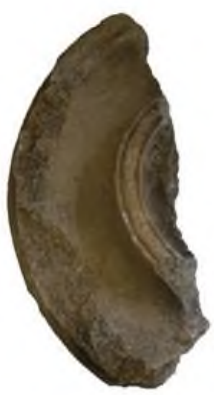

0

10

$20 \mathrm{~cm}$

Resim 6 
Tahir GÜRKAN - Osman DOĞANAY

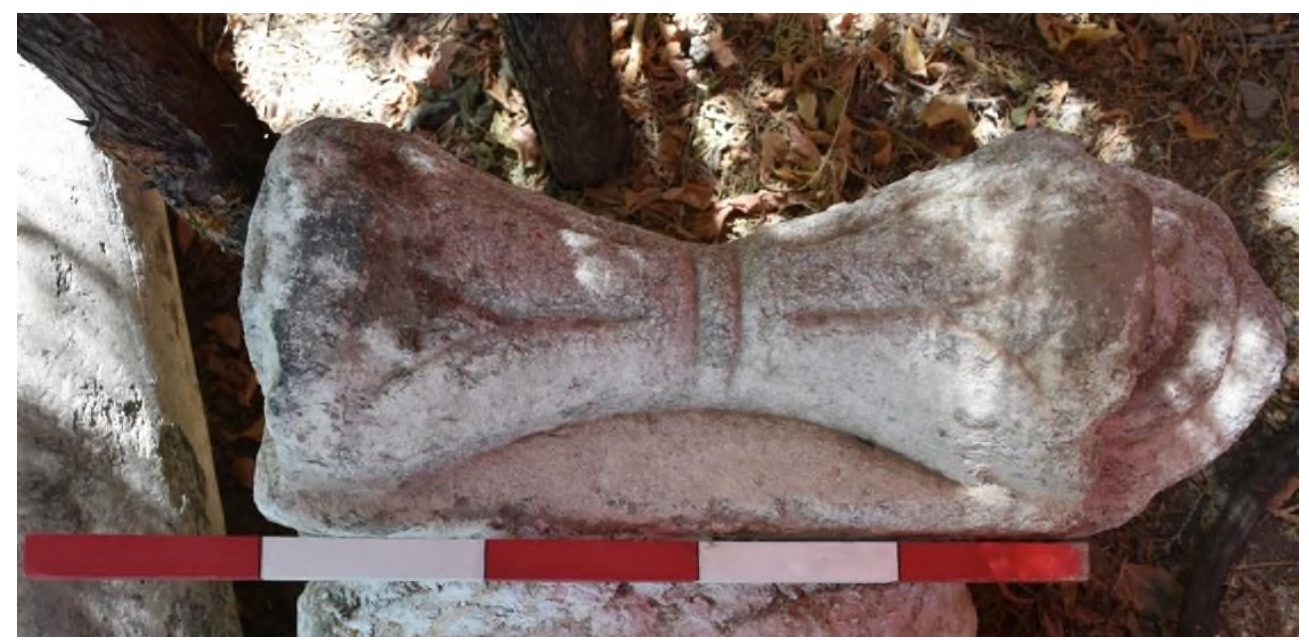

\section{Resim 7}
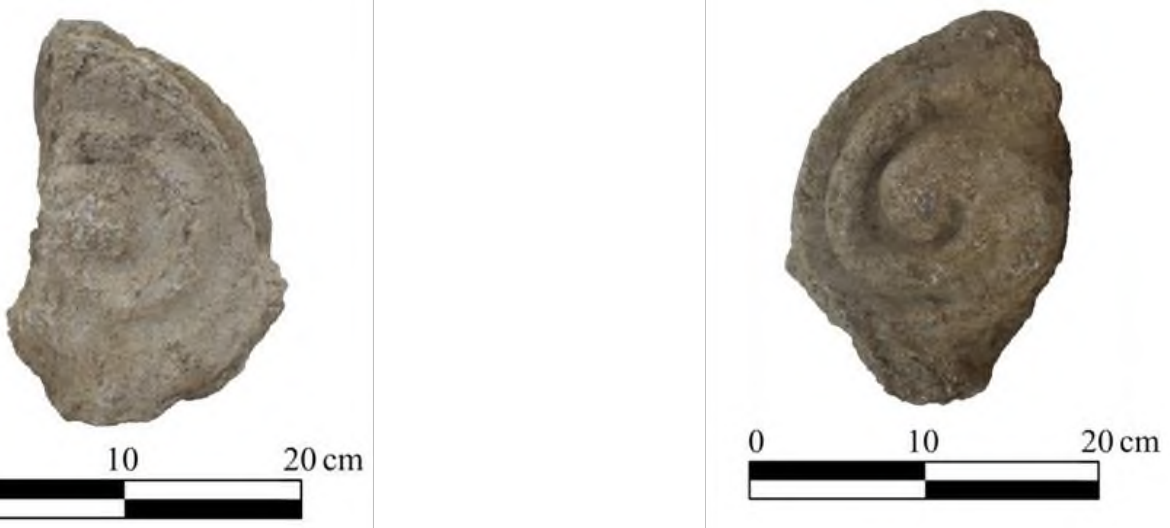

Resim 8 
Tyana Roma Hamamı Kazılarında Ortaya Çıkan Sütun Başlık Parçaları

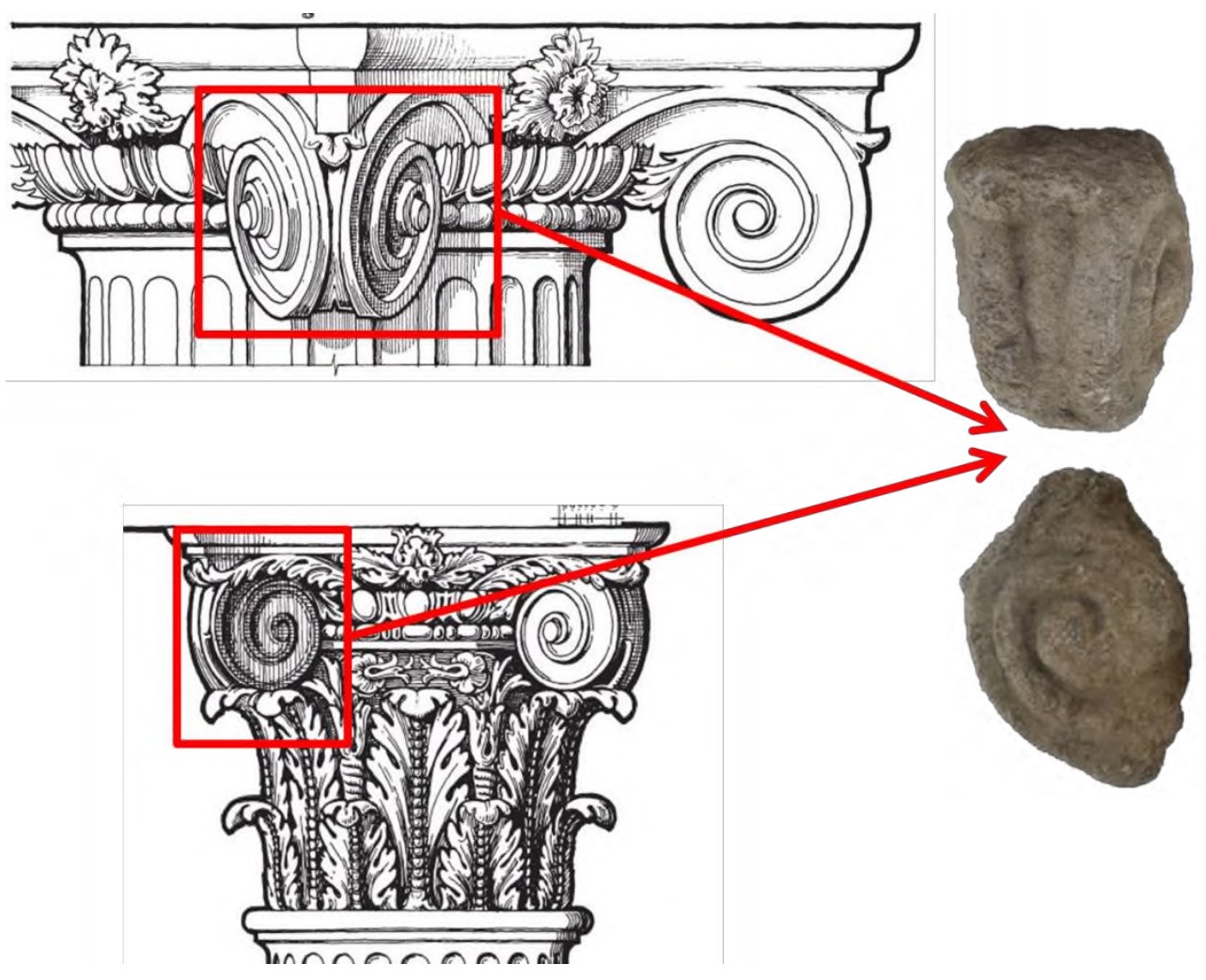

Resim 9
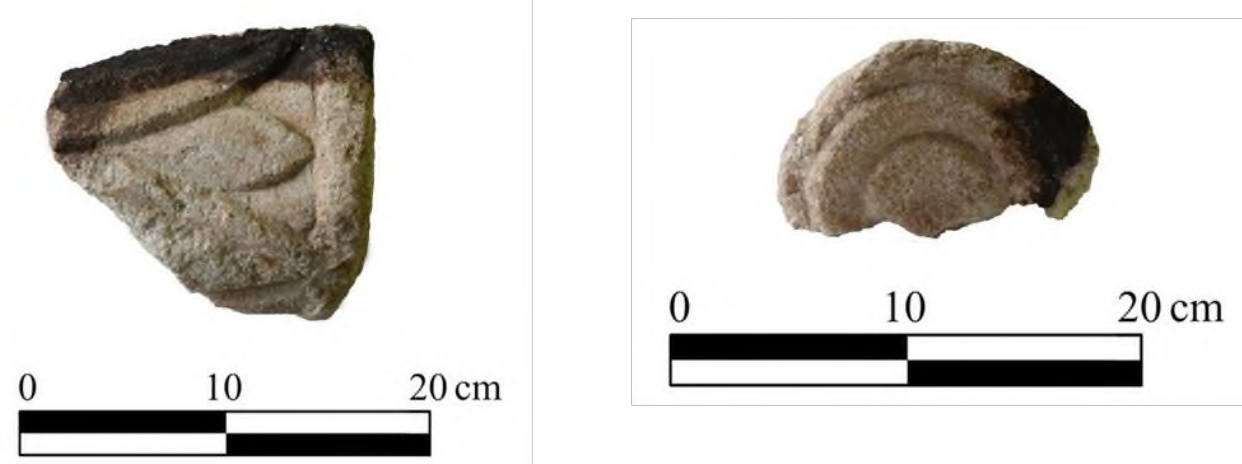

Resim 10 

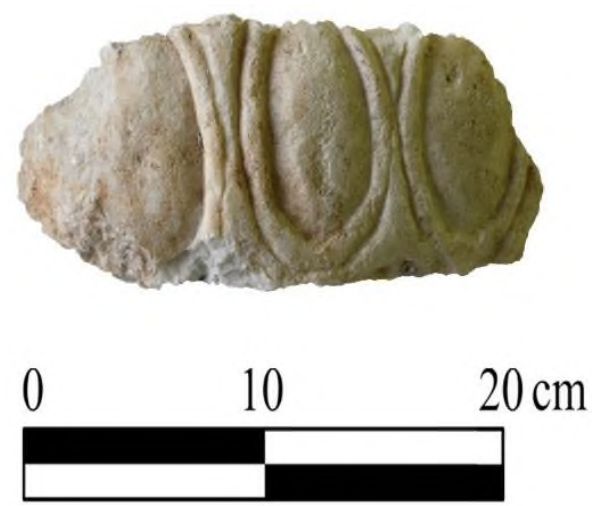

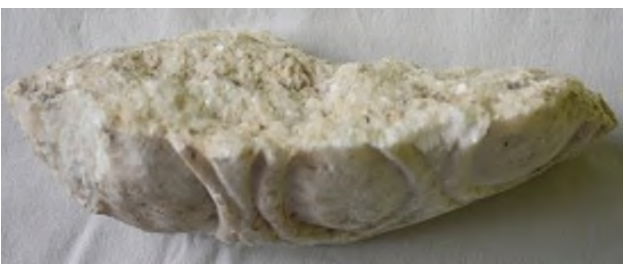

Resim 11
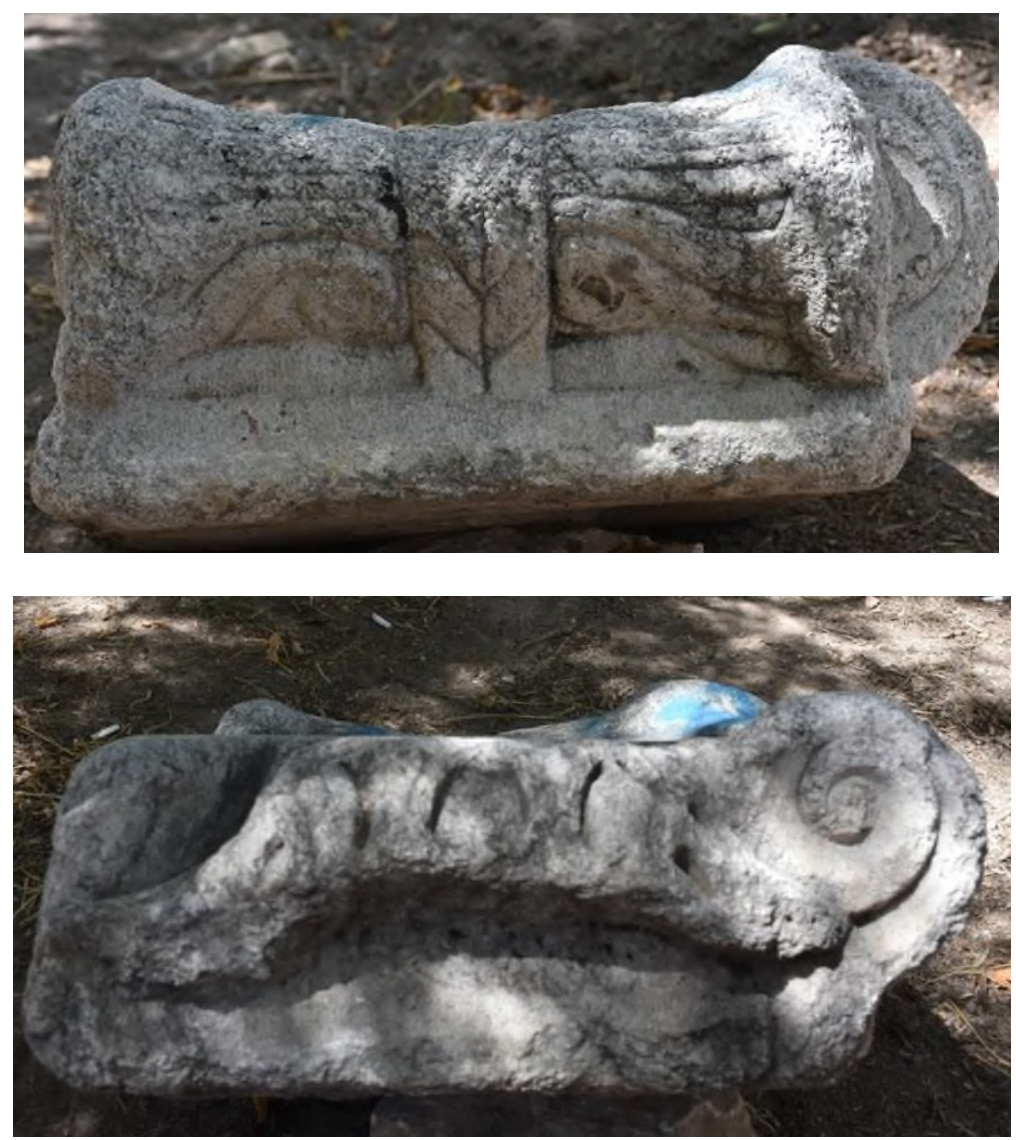

Resim 12 

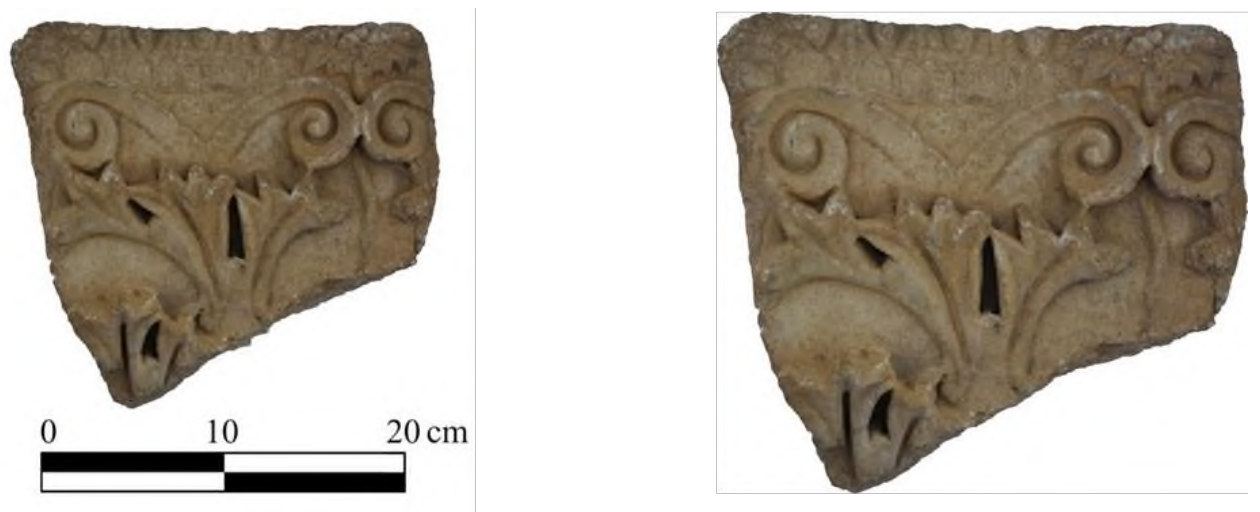

\section{Resim 13}
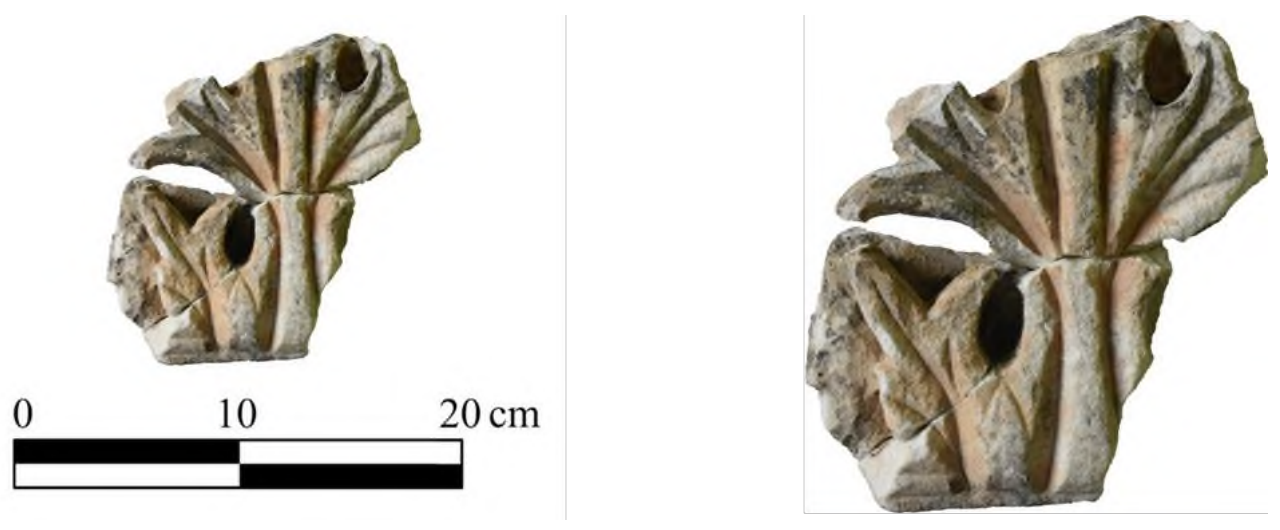

Resim 14 
Tahir GÜRKAN - Osman DOĞANAY
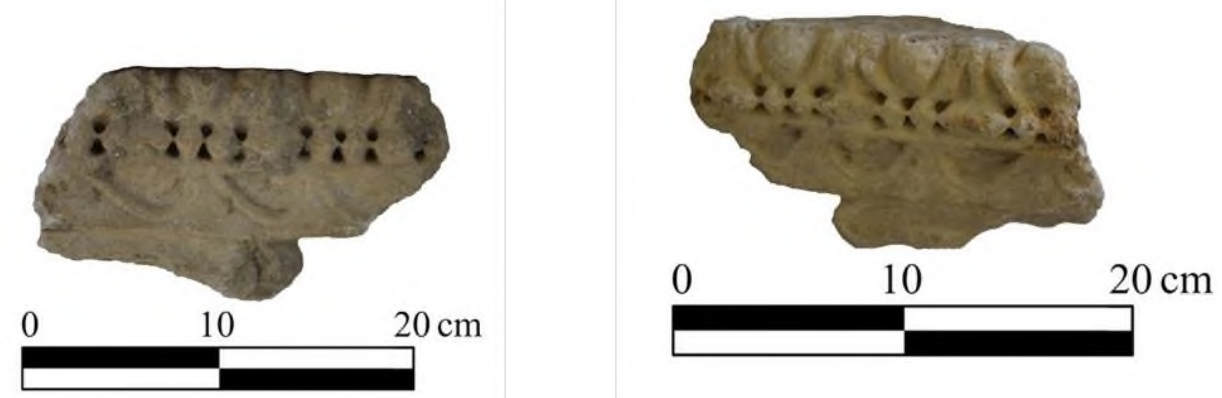

\section{Resim 15}
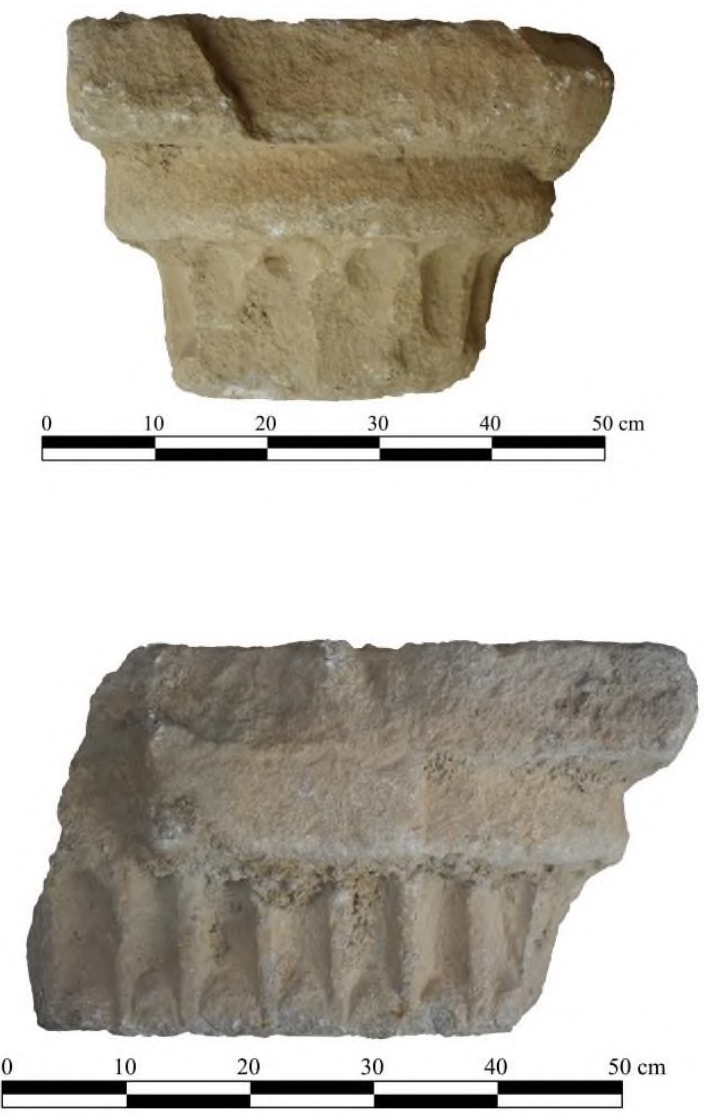

Resim 16 